\title{
CALIBRATION OF A STREAMFLOW-ROUTING MODEL FOR THE DELAWARE RIVER AND ITS PRINCIPAL TRIBUTARIES IN NEW YORK, NEW JERSEY, AND PENNSYLVANIA
}

by Herbert N. Flippo, Jr. and Thomas M. Madden, Jr.

U.S. GEOLOGICAL SURVEY

Water-Resources Investigations Report 93-4160

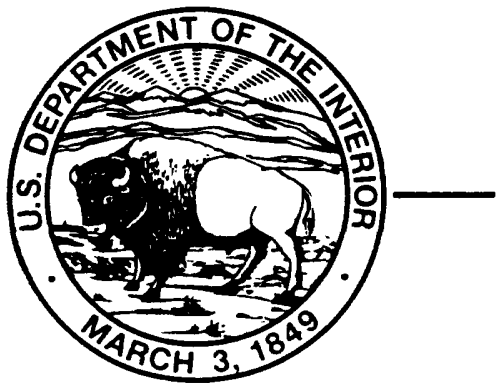




\title{
U.S. DEPARTMENT OF THE INTERIOR \\ BRUCE BABBITT, Secretary
}

\author{
U.S. GEOLOGICAL SURVEY
}

Gordon P. Eaton, Director

For additional information write to:

District Chief

U.S. Geological Survey

840 Market Street

Lemoyne, Pennsylvania 17043-1586
Copies of this report may be purchased from:

U.S. Geological Survey

Earth Science Information Center

Open-File Reports Section

Box 25286, MS 517

Denver Federal Center

Denver, Colorado 80225 


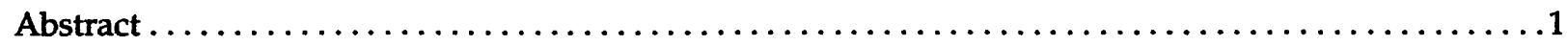

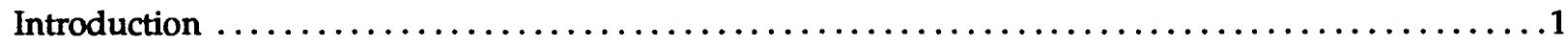

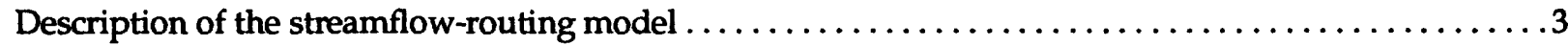

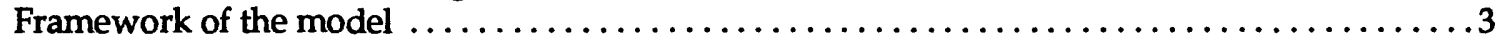

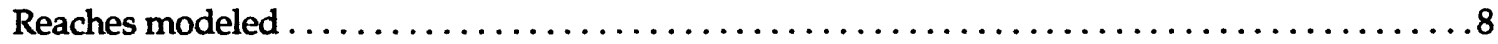

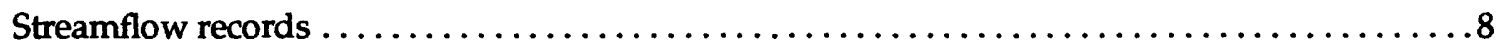

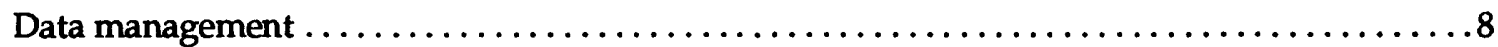

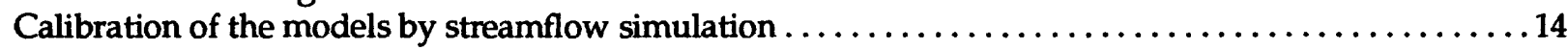

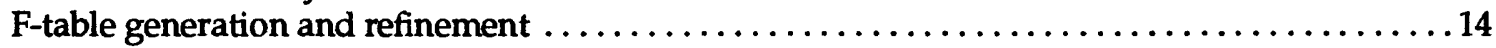

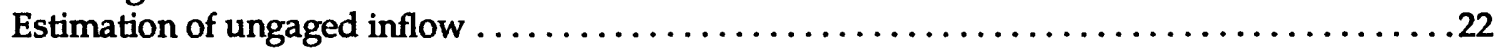

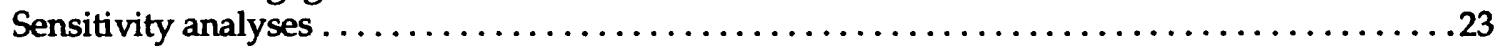

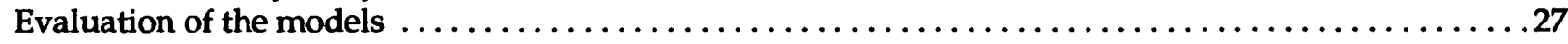

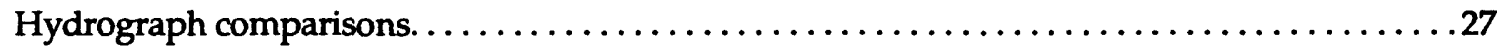

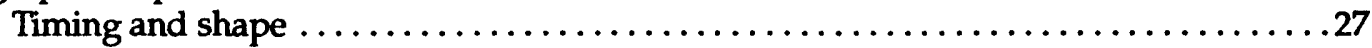

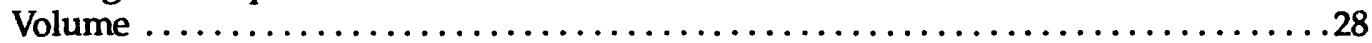

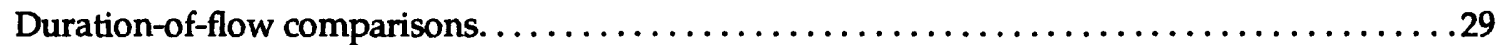

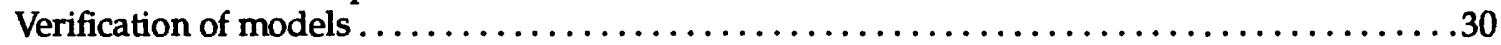

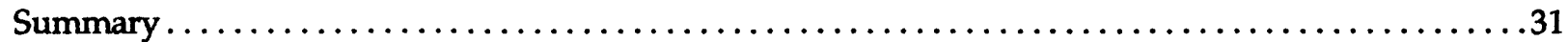

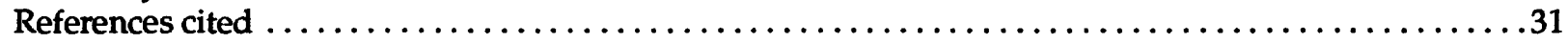




\section{ILLUSTRATIONS}

Page

Figure 1.-Flow diagram for the hydraulics section of the RCHRES application module. $\ldots \ldots 6$

2.-Graphical representation of solution to equations for determination of outflow rate

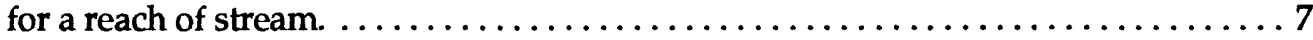

3.-Map showing drainage area of the Delaware River Basin and locations of principal reservoirs and stream gages that provided daily-discharge records for model calibration

4-6.--Graphs showing:

4.-Hydrographs of observed and simulated daily discharges for a 3-month lowflow period, Delaware River at Trenton, N.J. . . . . . . . . . . . . . 27

5.--Cumulative-frequency distributions of observed and simulated discharge of Delaware River at Trenton, N.J., for the calibration period, 1979-83. . . . . . . . 29

6.-Cumulative-frequency distributions of observed and simulated discharge of Delaware River at Trenton, N.J., for the verification period, August-October 1985.

\section{TABLES}

Table 1.-Example of user-control input for the RCHRES application module $\ldots \ldots \ldots \ldots \ldots \ldots$

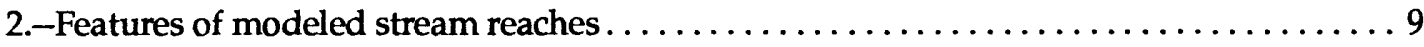

3.-Gaging stations from which daily discharge records were selected to develop routing

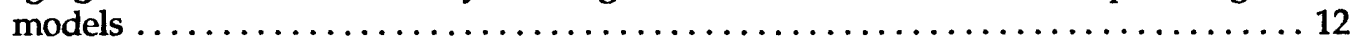

4.-F-tables for modeled stream reaches in the Delaware River Basin. . . . . . . . 16

5.--Gaging-station numbers of flow records and multiplication factors used to estimate inflows to the modeled reaches [Locations of reaches are shown in figure 3] . . . . 2 24

6.-Results of sensitivity tests of the routing factor and the storage component of the calibrated F-table for reach 13 on the Delaware River $\ldots \ldots \ldots \ldots \ldots \ldots \ldots \ldots \ldots \ldots$

7.-Summary of routing-model errors for the calibration period $1979-83 \ldots \ldots \ldots \ldots \ldots 28$ 
Multiply

foot $(\mathrm{ft})$

mile (mi)

acre

square mile $\left(\mathrm{mi}^{2}\right)$

cubic foot per second $\left(\mathrm{ft}^{3} / \mathrm{s}\right)$

acre-feet (acre-ft)
By

To obtain

Length

0.3048

1.609

meter

kilometer

Areg

4,047

2.590

Flow

0.02832

Volume

1,233 cubic meter per second

square meter

square kilometer

cubic meter

Sea level: In this report, "sea level" refers to the National Geodetic Vertical Datum of 1929 -- a geodetic datum derived from a general adjustment of the first-order level nets of the United States and Canada, formerly called Sea Level Datum of 1929. 


\title{
Calibration of a Streamflow-Routing Model for the Delaware River and Its Principal Tributaries in New York, New Jersey, and Pennsylvania
}

\author{
By Herbert N. Flippo, Jr. and Thomas M. Madden, Jr.
}

\begin{abstract}
The flow-routing module of the Hydrologic Simulation Program-Fortran watershed model was calibrated for 31 reaches on the Delaware River and 5 of its principal tributaries. These calibrations primarily involved the development of discharge-storage volume relations for the defined reaches. Daily discharge records for stream-gaging stations located at the upstream ends of the study reaches on the respective streams provided the primary hydrographic inputs for the routing models. Streamflow records for gaging stations at upstream locations and on other tributaries were used to estimate all other inflows for the 5-year calibration period, 1979-83. Root mean square errors of streamflows that were simulated for the downstream ends of gaged reaches ranged from 0.4 to 9.4 percent for the Delaware River, Lehigh River, Schuylkill River, and Brandywine Creek. Errors of 13 and 30 percent resulted from the streamflow simulations for the Lackawaxen and Neversink Rivers, respectively.
\end{abstract}

Verification simulations for a 3-month period of extreme low flows on the Delaware River in 1966 resulted in overestimation of discharges for the Trenton, N.J., gaging station by approximately 50 percent on many days. Observed (recorded) streamflows at the Trenton gaging station during this time were exceptionally low, owing to comparatively large diversions of flow for public supplies, and into the Delaware and Raritan Canal. A flow-verification simulation for 3 months of the summer and fall of 1985, during which time minimum flows in the basin were comparable to those of 1966, resulted in a root mean square error of 3.3 percent for the Trenton gaging station. There was no diversion to the Delaware and Raritan Canal at the time. Simulated flows closely matched observed flows for upstream gaging stations on the Delaware River as well, thereby confirming the routing calibration for this stream.

Information contained in this report can be used, with little modification, to develop routing modules for full-scale applications of the Hydrologic Simulation Program--Fortran model to the watersheds of the studied streams.

\section{INTRODUCTION}

In 1988, the U.S. Geological Survey (USGS) began a study to develop new insights into sensitivities of water resources to effects of climatic changes that may result from global warming in the next several decades (Ayers and Leavesley, 1988). Projections of climatic conditions, as made by general circulation models (GCM's) for a doubling of atmospheric carbon dioxide from its concentration in 1988, are used as the basis for evaluating potential changes in the availability of water in the Delaware River Basin and in water levels of the Delaware Estuary.

This study was focused on defining the basic relations between water-resource systems of the Delaware River Basin and current (1895-1988) climatic variables, and on assessing the sensitivities of these relations to climatic change. The principal objectives were to define the temporal and spatial variability of basin hydrology under existing climatic conditions, to develop climate-change scenarios, and to evaluate the potential responses, under these scenarios, of several aspects of the availability of surface and ground water: streamflow and water storage associated with the New York City and other reservoir systems; upstream movement of saline water in the Delaware Estuary caused by changes in sea level and freshwater inflow; and the concomitant intrusion of saltwater into aquifers adjacent to the Estuary (Ayers and others, 1989). 
A review of available hydrologic-simulation techniques that could be used to model the Delaware River Basin was made early in the investigation. This review indicated that application of Hydrologic Simulation Program-Fortran (HSPF) would provide a very satisfactory hydrologic model, owing to the versatility and comprehensiveness of its modeling capabilities. The HSPF computer program is a physically based, comprehensive mathematical mechanism for deterministically modeling watershed hydrologic response, water quality, agricultural chemical migration, and environmental risk (U.S. Environmental Protection Agency, 1984). Full application of HSPF proved impractical because the digital data bases containing the necessary geographic coverages of geologic, soil, land-use, and climatic information were incomplete for the basin. It was beyond the scope of the study to assemble the huge amount of data needed to apply HSPF fully. Subsequently, the TOPMODEL precipitation-runoff modeling technique (Beven and Kirkby, 1979) was chosen to model the hydrology of the basin (Wolock, 1993) for three hydrologic-sensitivity evaluations of ine climate change. TOPMODEL requires much less input data than does HSPF, but it yields sufficiently accurate estimates of streamflow to stochastically evaluate the effects of changes in climate.

In anticipation of future needs for a more precise flow-routing model than that provided by TOPMODEL, the streamflow-routing module of HSPF was applied to the Delaware River and its principal tributaries. The quality of a time ser: ... of streamflow values that are synthetically generated by HSPF or by any other rainfall-runoff model of basin can best be evaluated on the basis of how well these values replicate observed streamflow data. The purpose of this study was to develop the channel-routing calibration that would be needed to ruate time ss of generated streamflows through the basin reliably. Calibration of HSPF's routing-application module, RCHRES, to the range of flows that have been observed at gaging stations, was necessary to $i$ " "ure that this routing model will realistically simulate the translation of synthetically computed runoff along major stream channels. This report summarizes the procedures used in that calibration, the accuracies of calibration for various stream segments, and the results of model verification.

The following streams were selected for flow-routing calibration: East Branch Delaware River from Pepacton Reservoir to confluence with West Branch Delaware River; West Branch Delaware River from Cannonsville Reservoir to confluence with East Branch Delaware River; Delaware River from confluence of East and West Branches to Trenton, N.J.; Lackawaxen River, from Prompton Reservoir on the West Branch and from General Edgar Jadwin Reservoir on Dyberry Creek to confluence with Delaware River; Neversink River from Neversink Reservoir to confluence with Delaware River; Lehigh River from Francis E. Walter Lake to confluence with Delaware River; Schuylkill River from Landingville, Pa., and Little Schuylkill River from Tamaqua, Pa., to confluence with the Delaware Estuary; and Brandywine Creek, from Modena, Pa., on the West Branch and from Downingtown, Pa., on the East Branch, to confluence with Christina River.

Hydraulic conditions upstream from the modeled segments and their contiguous reservoirs, as well as inflows from small tributaries to principal stream channels, are expected to have minor effects on hydrographic response in the Delaware River, in the lower reaches of principal tributaries, or in the estuary. Therefore, upstream and minor tributary reaches were not modeled for flow routing. 


\section{DESCRIPTION OF THE STREAMFLOW-ROUTING MODEL.}

Eramework of the Model

The HSPF modeling system consists of a large set of software modules that simulate quantity and quality of water in various hydrologic processes. These modules are arranged in a hierarchical structure. The user-oriented, structured design permits convenient inclusion of various simulation and utility modules, either individually or in combination. Streamflow-routing models developed for the Delaware River and its principal tributaries are applications solely of the RCHRES module. Complete documentation for Release 9.0 of the HSPF system is contained in the Users Manual (U.S. Environmental Protection Agency, 1984).

The RCHRES module is designed to simulate the propagation of streamflows and several waterquality constituents through channel segments and reservoirs. Simulations of streamflow require use of the hydraulics section (HYDR) of this module. It is executed by inclusion of indicator flags for activation, specifications of input and output files for the time series of stream discharges, identification of the desired options of hierarchical calculations used in computing volumes of water stored in and entering the stream reaches (or reservoirs), and function tables (F-tables) that relate reach volumes to specified discharge magnitudes. The user-control input necessary to run the module is coded into operational blocks in a prescribed 80-character record. An example of user-control input for calibrated contiguous reaches is shown in table 1 . This example constitutes the RCHRES model for the main stem of the Delaware River from the East Branch Delaware River to Trenton, N.J.

Table 1. Example of user-control input for the RCHRES application module

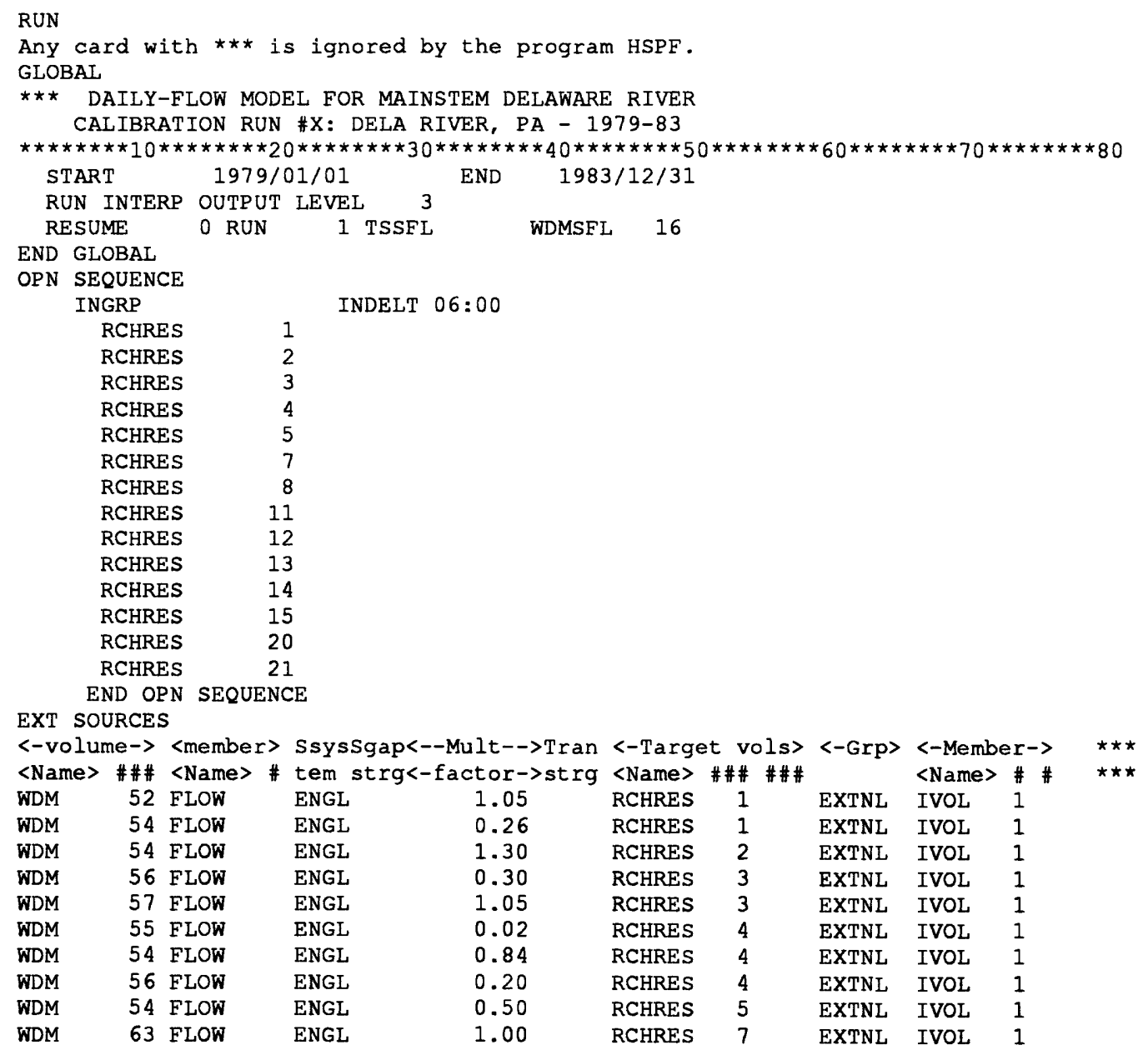


Table 1. Example of user-control input for the RCHRES application module-Continued

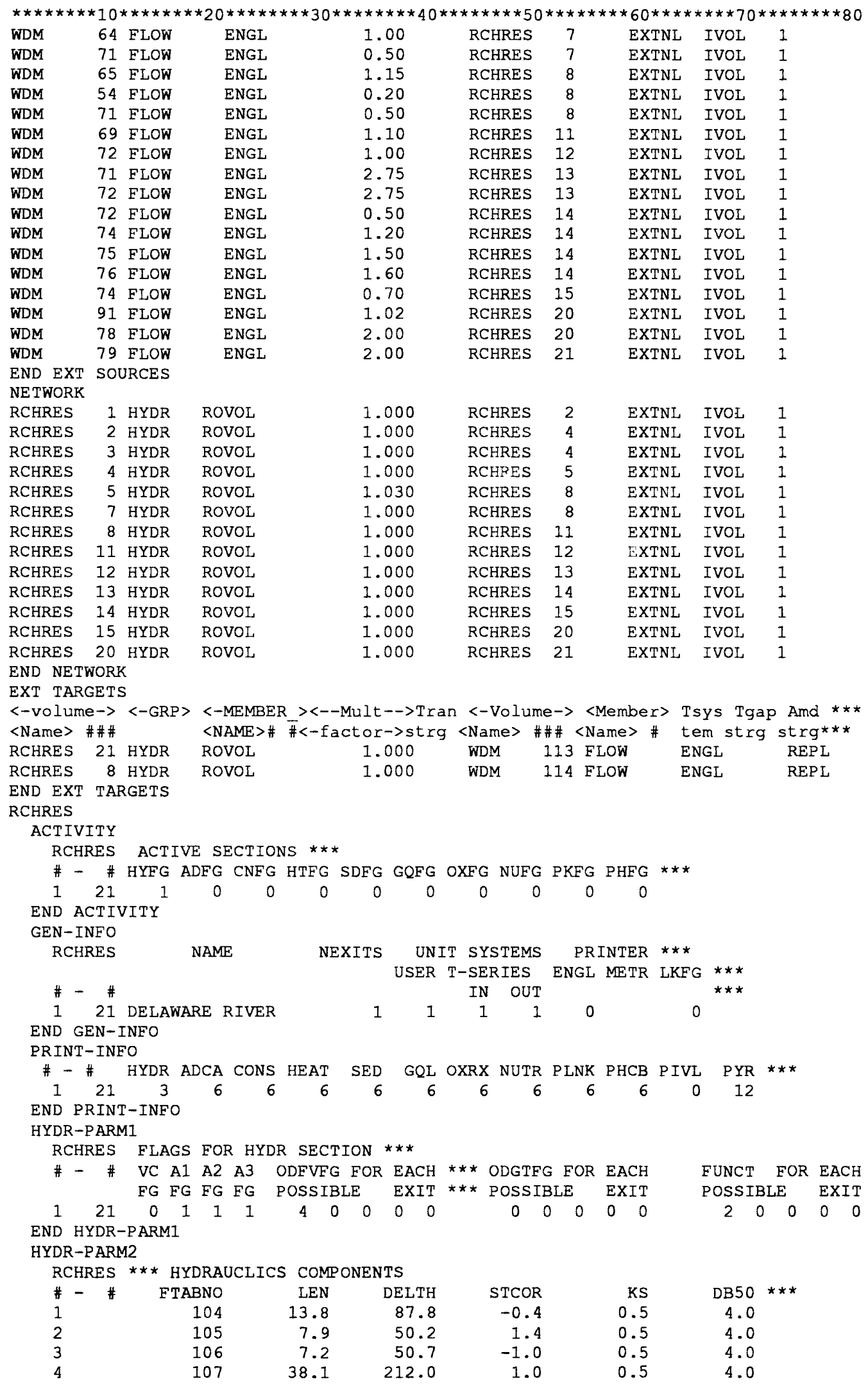


Table 1. Example of user-control input for the RCHRES application module-Continued

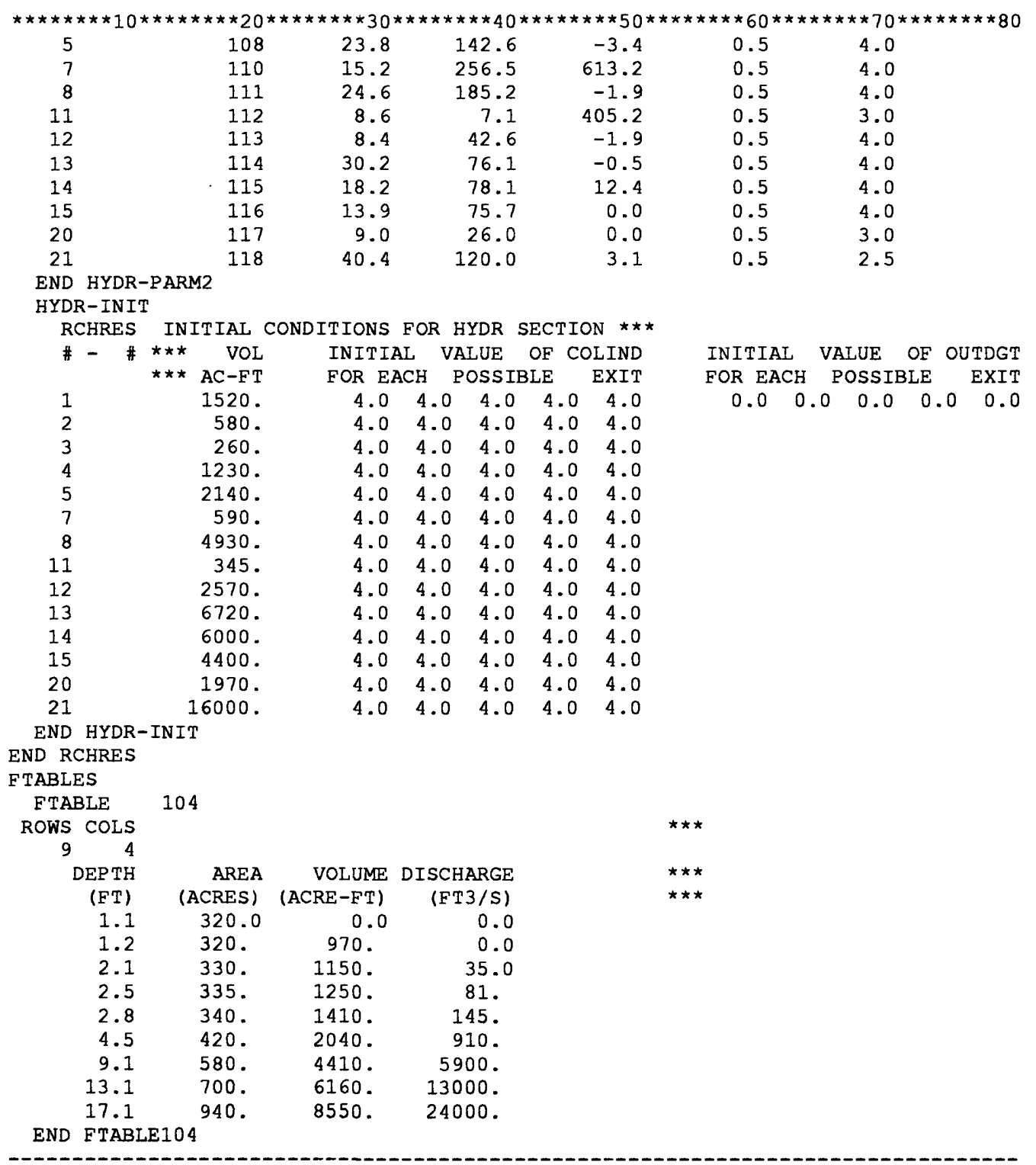

(F-tables, for each reach, continue)

END FTABLES

END RUN 
The RCHRES module simulates the movement of volumes of water through each designated reach in a unidirectional, step-wise "storage-routing" process. The time step is ordinarily the time interval of the input flow values, such as "daily." However, a provision to partition input streamflow values into onequarter time steps, or a 6-hour partition of daily values, greatly enhances hydrographic simulation when the traveltime for flow is less than the time interval of the input flows, as might occur when a daily time step is used for a short reach of stream.

A schematic diagram for the application of the HYDR section to streamflow in a reach (or reservoir) is shown in figure 1. All inflows to the reach (code-named IVOL), regardless of the actual physical point of entry, are input at the start of routing. These accumulated inflows are designated VOL within the reach. Natural fluxes of water in a reach, PRSUPY and VOLEV for precipitation and evaporation in figure 1, were deemed inconsequential to the development of the routing models because they have no bearing on the volume-discharge relations for the stream channels. These fluxes could be easily included by adding the climatic data to the time-series file. Outflows (OVAL) can be routed to as many as five exits. The total of these outflows is code-named ROVOL.

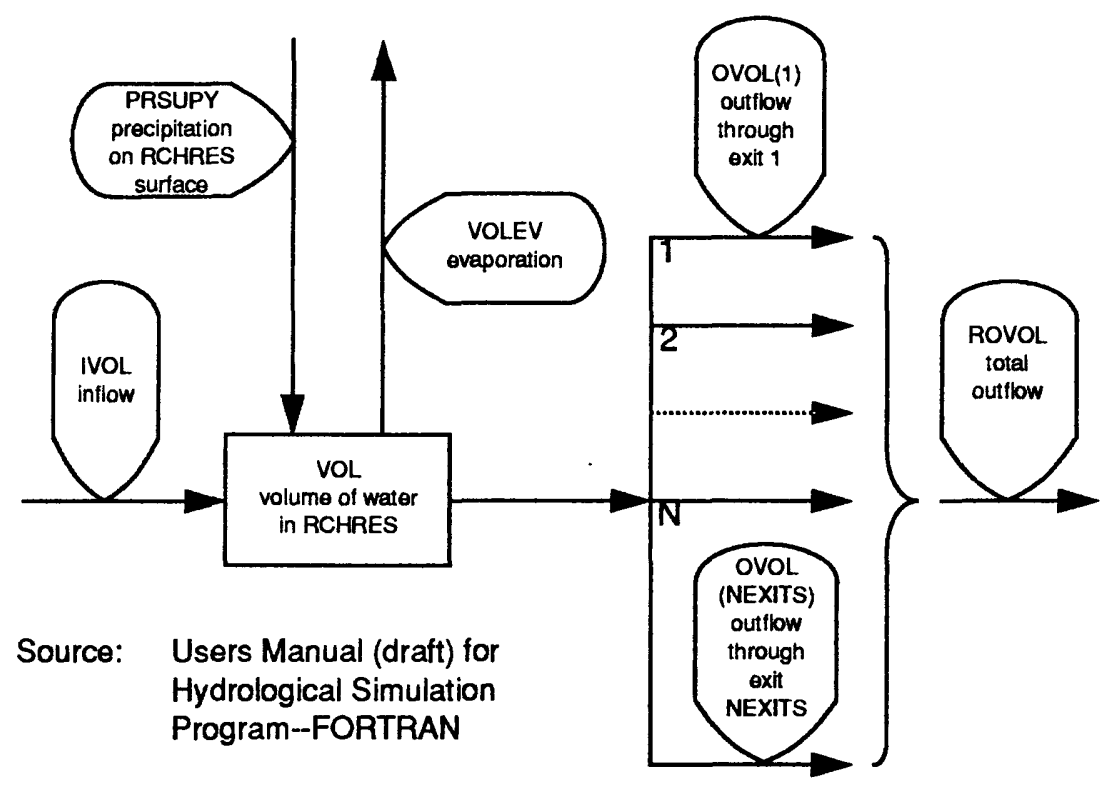

Figure 1. Flow diagram for the hydraulics section of the RCHRES application module. (From U.S. Environmental Protection Agency, 1984, fig. 4.2(3).1-1)

The routing method is based on the continuity equation

$$
\text { VOLE - VOLS = IVOL - ROVOL, }
$$

where VOLE is volume at the end of the simulation interval,

VOLS is volume at the start of the simulation interval, and

IVOL and ROVOL are as previously defined.

Equation 1 can be written as

$$
\text { VOLE }=\text { VOLT }- \text { ROVOL , }
$$

where VOLT is IVOL + VOLS. 
The volume at the end of the simulation interval (VOLE) is derived with Equation 2, for which ROVOL is estimated by

$$
\text { ROVOL }=\left(K S^{*} \text { ROS }+ \text { COKS*ROD }\right)^{*} \text { DELTS, }
$$

where $\mathrm{KS}$ is a weighting factor (between 0 and 1.00),

ROS is total rate of outflow from the reach at the start of the interval,

COKS is $1.00-\mathrm{KS}$,

ROD is total rate of outflow demand for the end of the interval, and

DELTS is the simulation interval, in seconds.

In conjunction with COKS, KS serves as a mechanism for differential weighting of inflow and outflow rates. It is selected by the user or, alternatively, by default. A value of 0.5 , or slightly less, usually gives the most accurate results.

Equation 2 can be rewritten as

$$
\text { VOL }=\text { VOLT }-\left(K^{*} R O S+\text { COKS*ROD }\right)^{*} \text { DELTS } .
$$

Another relation is needed to solve for unknowns VOL and ROD. ROD can be a function of VOL and a demand (or a diversion), which is a function of time, $t$. Thus;

$$
\text { ROD }=\text { function }(V O L, t) \text {. }
$$

If streamflow is not diverted from a reach as a function of date and time, then

$$
\text { ROD }=\text { function(VOL). }
$$

The solution of Equations 4 and 6 provides the total rate of outflow (discharge) at the end of each interval in such a simulation. Figure 2 shows that the point of intersection of Equations 4 and 6 provides a rate of outflow for the specified VOL in the reach at the end of any time step. The average outflow rate for the DELTS intervals in a time step (for example, 1 day) is the average discharge. Several outflow demands, or discharges, may be volume dependent. The most simple application for the functional relations assumes (1) a fixed relation exists between water-surface elevation, surface area, and volume; and (2) the functional relation between volume (VOL) and outflow demand (discharge) is constant in time. There are capabilities in RCHRES for varying the functional relation with time or season, but no attempts were made to incorporate the minor refinements of such capabilities in this application. The volume-discharge relation (equation 6) is specified in an F-table for the reach, which also specifies the associated values for depth and surface area. F-tables may be included in the user control input (table 1) or they may be stored in a Watershed Data Management file, which is a file of data in a special binary format. This file was used for all inputs and outputs of time-series data for the simulations of this study.

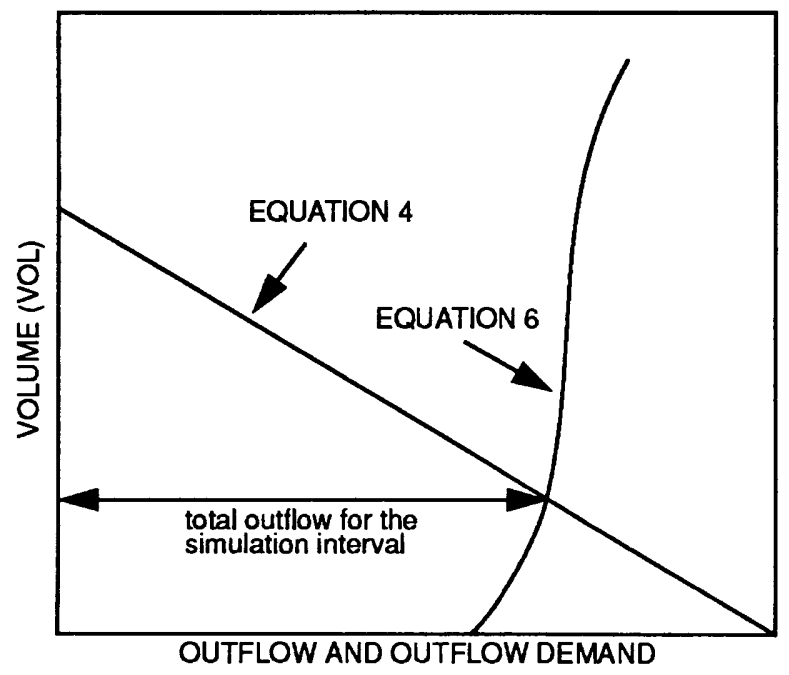

Figure 2. Graphical representation of solution to equations for determination of outflow rate for a reach of stream. (From U.S. Environmental Protection Agency, 1984, fig. 4.2(3).1-2) 
Statistical measures of streamflow were used to specify outflow demands that functionally relate to volumes for each of the study reaches. To span the range of most flows and to provide adequate resolution to the functional relations between discharge and volume, the following eight statistical measures of flow were selected for the F-tables: zero; 7-day, 10-year low; 10th, 50th, and 90th duration percentiles; and 2-, 10-, and 100-year flood magnitudes. Discharge rates for these statistical flows were determined by application of WATSTORE (Hutchinson, 1975) statistical programs to those daily and peak discharge records that are representative of current hydrologic conditions. Discharge rates at ungaged sites were interpolated from per-square-mile values at gaged sites and drainage areas. Discharges determined for the 10- and 100-year floods are consistent with those reported in Flood Insurance Studies published by the Federal Emergency Management Agency.

\section{Reaches Modeled}

The modeled streams, as described in the Introduction, were subdivided into 31 reach segments, the end points of which coincide with stream-gaging stations or confluence sites. Features of these reaches, including length, end-point sites, upper-end and lower-end drainage areas, downstream elevation of water-surface at median flow, average slope, and a discharge-weighting factor for calculating streamflows in the simulation interval, are shown in table 2.

Figure 3 shows the drainage basin of the study area, locations of streamflow-gaging stations that provided the daily flow records used to develop the models, and the locations of principal reservoirs. Streamflow records for 53 gaging stations were used directly in model development. Records for the most downstream gaging stations oni the Delaware River, Schuylkill River, and Brandywine Creek were used to verify routed daily flows for these streams.

\section{Streamflow Records}

Records of daily mean streamflows that were used to calibrate and verify the HSPF models are those for various USGS streamflow-gaging stations in the Delaware River Basin. These records are maintained in the "Daily Values" computer tue of the WATSTORE (Hutchinson, 1975) data-storage system. Table 3 presents the downstream-order listing of the gaging stations. The drainage areas at these gaging stations and the river-mile locations of gaging stations within modeled reaches are included in this table. Daily discharges for gaging stations at ihe downstream ends of modeled reaches, as listed in table 2, are the hydrographic record that the models were calibrated to replicate. Discharge records for the other gaging stations provided hydrographic input at the upstream ends of the modeled streams, hydrographs of gaged tributary inflows, and a basis for estimating ungaged tributary inflows.

\section{Data Management}

Input and output data for the RCHRES application module, except for F-tables directly input by the user control code, were managed with the computer program AiNNIE (Lumb and others, 1990). ANNIE stores hydrologic data in a direct-access, binary data library called a Watershed Data Management (WDM) file. In addition to the usual desirable functions for manipulating time-series data for hydrologic-modeling purposes-create, input, add, modify, copy, select, transform, pa :tition, adjust time coordinates, export, and delete-these data can be tabulated, graphed, and subjected to selected statistical analyses. Plots and statistical summaries of time-series data shown elsewhere in this report were prepared with ANNIE.

The HSPF models and ANNIE were run with a Prime ${ }^{1}$ 9955-II computer.

\footnotetext{
1 The use of brand names in this repo $c_{\perp}$ is tor identifiction purposes only and does not constitute endorsement by the U.S. Geological Survey.
} 
Table 2. Features of modeled stream reaches

\begin{tabular}{|c|c|c|c|c|c|c|c|}
\hline Stream & $\begin{array}{l}\text { Reach } \\
\text { number }^{1}\end{array}$ & $\begin{array}{l}\text { End points (gaging } \\
\text { station numbers or } \\
\text { other sites) }\end{array}$ & $\begin{array}{l}\text { Length } \\
\text { (miles) }\end{array}$ & $\begin{array}{c}\text { Range of } \\
\text { drainage } \\
\text { areas } \\
\text { (square } \\
\text { miles) }\end{array}$ & $\begin{array}{c}\text { Downstream } \\
\text { elevation } \\
\text { of median } \\
\text { stage } \\
\text { (feet above } \\
\text { sea level) }\end{array}$ & $\begin{array}{c}\text { Slope } \\
\text { (feet } \\
\text { per } \\
\text { mile) }\end{array}$ & $\mathrm{KS}^{2}$ \\
\hline $\begin{array}{l}\text { East Branch } \\
\text { Delaware River }\end{array}$ & 1 & 01417000 to 01417500 & 13.8 & $372-458$ & $1,009.78$ & 6.36 & 0.5 \\
\hline Do. & 2 & 01417500 to 01421000 & 7.9 & $458-784$ & 959.61 & 6.35 & .5 \\
\hline $\begin{array}{l}\text { West Branch } \\
\text { Delaware River }\end{array}$ & 3 & 01425000 to 01426500 & 7.2 & $456-595$ & 949.21 & 7.04 & .5 \\
\hline Delaware River & 4 & 01421000 \& 01426500 to 01427510 & ${ }^{3} 38.1$ & $1,379-1,820$ & 738.14 & 5.56 & .5 \\
\hline Do. & 5 & 01427510 to 01428500 & 23.8 & $1,820-2,020$ & 603.72 & 5.65 & .5 \\
\hline Lackawaxen River & 6 & $01429000 \& 01429500$ to 01431500 & ${ }^{4} 14.0$ & $124-290$ & 871.30 & 11.3 & .5 \\
\hline Do. & 7 & 01431500 to Delaware River & 16.2 & $290-598$ & ${ }^{4} 615$ & 15.8 & .5 \\
\hline Delaware River & 8 & 01428500 to 01434000 & 24.6 & $2,020-3,070$ & 418.51 & 7.53 & .5 \\
\hline Neversink River & 9 & 01436000 to 01436500 & 5.3 & $93-113$ & ${ }^{5} 1,182$ & 14.4 & .5 \\
\hline Do. & 10 & 01436500 to 01437500 & 26.7 & $113-307$ & 463.10 & 26.9 & .5 \\
\hline Do. & 11 & 01437500 to Delaware River & 8.6 & $307-354$ & ${ }^{5} 407$ & 6.5 & .5 \\
\hline Delaware River & 12 & 01434000 to 01438500 & 8.4 & $3,070-3,480$ & 375.95 & 5.07 & .5 \\
\hline Delaware River & 13 & 01438500 to 01440200 & 30.2 & $3,480-3,850$ & 299.81 & 2.52 & .5 \\
\hline Do. & 14 & 01440200 to 01446500 & 18.4 & $3,850-4,535$ & 231.11 & 3.77 & .5 \\
\hline Do. & 15 & 01446500 to above Lehigh River & 13.9 & $4,535-4,717$ & ${ }^{5} 155.0$ & 5.48 & .5 \\
\hline Lehigh River & 16 & 01447800 to ${ }^{5} 01449000$ & 37.3 & $290-591$ & 446.88 & 20.6 & .5 \\
\hline Do. & 17 & 601449000 to 01451000 & 9.3 & $591-889$ & 352.89 & 10.1 & .5 \\
\hline Do. & 18 & 01451000 to 01453000 & 21.9 & $889-1,279$ & 213.00 & 6.39 & .5 \\
\hline Do. & 19 & 01453000 to Delaware River & 11.8 & $1,279-1,361$ & ${ }^{6} 172.0$ & 3.47 & .4 \\
\hline Delaware River & 20 & Above Lehigh River to 01457500 & 9.0 & $4,717-6,328$ & 129.4 & 2.84 & .5 \\
\hline Do. & 21 & 01457500 to 01463500 & 40.4 & $6,328-6,780$ & 9.35 & 2.97 & .5 \\
\hline Schuylkill River & 22 & $\begin{array}{l}01468500 \text { to above Little } \\
\text { Schuylkill River }\end{array}$ & 22.4 & $133-340$ & 5380.0 & 9.92 & .5 \\
\hline Schuylkill River & 23 & $\begin{array}{l}\text { Above Little Schuylkill } \\
\text { River to } 01470500\end{array}$ & 5.9 & $340-355$ & 315.89 & 10.8 & .5 \\
\hline Do. & 24 & 01470500 to 01471510 & 19.8 & $355-880$ & 188.63 & 6.43 & .5 \\
\hline Do. & 25 & 01471510 to 01472000 & 22.0 & $880-1,147$ & 120.08 & 3.12 & .5 \\
\hline Do. & 26 & 01472000 to above Perkiomen Creek & 22.0 & $1,147-1,375$ & ${ }^{5} 72$ & 2.2 & .5 \\
\hline Do. & 27 & $\begin{array}{l}\text { Above Perkiomen Creek to Delaware } \\
\text { River }\end{array}$ & 31.7 & $1,375-1,912$ & ${ }^{5} 1.3$ & 2.2 & .4 \\
\hline $\begin{array}{l}\text { West Branch } \\
\text { Brandywine Creek }\end{array}$ & 28 & $\begin{array}{l}01480617 \text { to junction with East } \\
\text { Branch Brandywine Creek }\end{array}$ & 13.3 & $55-135$ & ${ }^{5} 171.3$ & 7.1 & .5 \\
\hline $\begin{array}{l}\text { East Branch } \\
\text { Brandywine Creek }\end{array}$ & 29 & $\begin{array}{l}01480870 \text { to junction with West } \\
\text { Branch Brandywine Creek }\end{array}$ & 5.0 & $90-124$ & ${ }^{5} 171.3$ & 5.2 & .4 \\
\hline Brandywine Creek & 30 & $\begin{array}{l}\text { Junction of East and West Branches to } \\
01481000\end{array}$ & 5.3 & $259-287$ & 152.27 & 3.5 & .4 \\
\hline Do. & 31 & 01481000 to Christina River & 14.8 & $287-300$ & $5_{1}$ & 10.2 & .4 \\
\hline
\end{tabular}

\footnotetext{
1 See figure 3 for distribution of designated stream reaches.

${ }^{2}$ A weighting factor that is applied, at the beginning of the simulation interval, to the discharge from a routing reach. The factor (1-KS) is applied to the discharge from the reach at the end of the simulation interval. The product of the simulation interval, in seconds, and the sum of these two weighted discharges equals the simulated volume of water leaving the reach during the simulation interval.

${ }^{3}$ Discharge-weighted distance from the two upstream gaging stations to the downstream station.

${ }^{4}$ Estimated from topographic maps or stream cross-sectional data.

${ }^{5}$ Stream-gaging station operational since October 1, 1982.

${ }^{6}$ Estimated for dam site at mouth.
} 


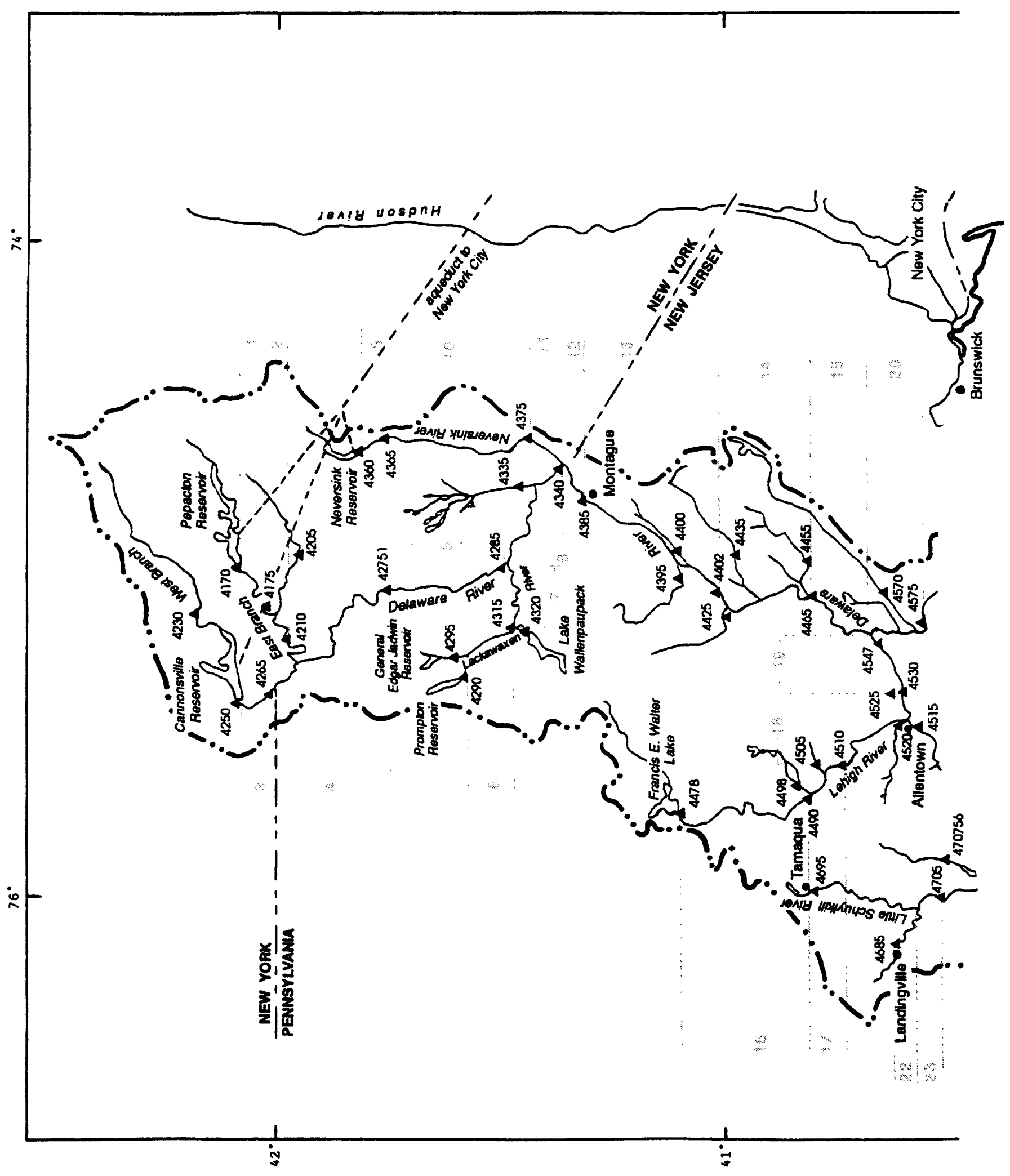




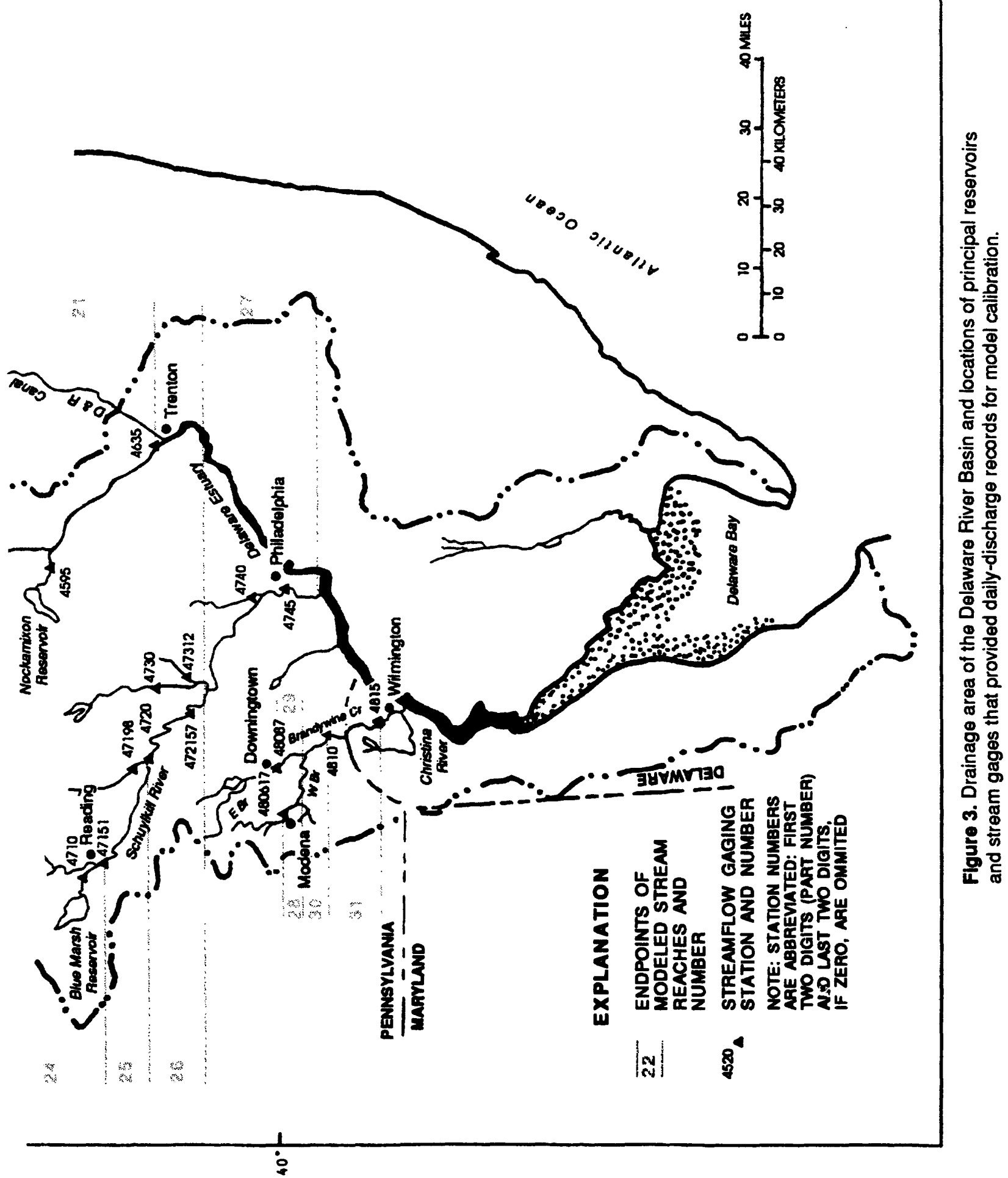


Table 3. Gaging stations from which daily discharge records were selected to develop routing models $\left[\mathrm{mi}^{2}\right.$, square mile]

\begin{tabular}{|c|c|c|c|}
\hline $\begin{array}{c}\text { Station } \\
\text { number }^{1}\end{array}$ & Station name & $\begin{array}{c}\text { Drainage } \\
\text { area } \\
\left(\mathrm{mi}^{2}\right)\end{array}$ & River mile ${ }^{2}$ \\
\hline 01417000 & East Branch Delaware River at Downsville, N.Y. & 371 & 363.6 \\
\hline 01417500 & East Branch Delaware River at Harvard, N.Y. & 457 & 349.8 \\
\hline 01420500 & Beaver Kill at Cooks Falls, N.Y. & 241 & - \\
\hline 01421000 & East Branch Delaware River at Fishs Eddy, N.Y. & 783 & 341.9 \\
\hline 01423000 & West Branch Delaware River at Walton, N.Y. & 331 & - \\
\hline 01425000 & West Branch Delaware River at Stilesville, N.Y. & 456 & 16.8 \\
\hline 01426500 & West Branch Delaware River at Hale Eddy, N.Y. & 593 & 9.6 \\
\hline 01427510 & Delaware River at Callicoon, N.Y. & 1,882 & 303.1 \\
\hline 01428500 & Delaware River above Lackawaxen River near Barryville, N.Y. & 2,023 & 279.3 \\
\hline 01429000 & West Branch Lackawaxen River at Prompton, Pa. & 59.7 & 31.2 \\
\hline 01429500 & Dyberry Creek near Honesdale, Pa. & 64.6 & ${ }^{3} 29.3$ \\
\hline 01431500 & Lackawaxen River at Hawley, Pa. & 290 & 16.2 \\
\hline 01432000 & Wallenpaupack Creek at Wilsonville, Pa. & 228 & - \\
\hline 01433500 & Mongaup River near Mongaup, N.Y. & 202 & - \\
\hline 01434000 & Delaware River at Port Jervis, N.Y. & 3,076 & 254.7 \\
\hline 01436000 & Neversink River at Neversink, N.Y. & 91.9 & 40.6 \\
\hline 01436500 & Neversink River at Woodbourne, N.Y. & 113 & 35.3 \\
\hline 01437500 & Neversink River at Godeffroy, N.Y. & 307 & 8.6 \\
\hline 01438500 & Delaware River at Montague, N.J. & 3,480 & 246.3 \\
\hline 01439500 & Bush Kill at Shoemakers, Pa. & 117 & - \\
\hline 01440000 & Flat Brook near Flatbrookville, N.J. & 64.0 & - \\
\hline 01440200 & Delaware River below Tocks Island damsite, near Delaware Water Gap, Pa. & 3,850 & 216.1 \\
\hline 01442500 & Broadhead Creek at Minisink Hills, Pa. & 259 & - \\
\hline 01443500 & Paulins Kill at Blairstown, N.J. & 126 & - \\
\hline 01445500 & Pequest River at Pequest, N.J. & 106 & - \\
\hline 01446500 & Delaware River at Belvidere, N.J. & 4,535 & 197.7 \\
\hline 01447800 & Lehigh River below Francis E. Walter Lake near White Haven, Pa. & 290 & 76.3 \\
\hline 01449000 & Lehigh River at Lehighton, $\mathrm{Pa}$. & 591 & 43.0 \\
\hline 01449800 & Pohopoco Creek below Beltzville Dam near Parryville, Pa. & 96.4 & - \\
\hline 01450500 & Aquashicola Creek at Palmerton, $\mathrm{Pa}$. & 76.7 & - \\
\hline
\end{tabular}


Table 3. Gaging stations from which daily discharge records were selected to develop routing models--Continued $\left[\mathrm{mi}^{2}\right.$, square mile]

\begin{tabular}{|c|c|c|c|}
\hline $\begin{array}{l}\text { Station } \\
\text { number }^{1}\end{array}$ & Station name & $\begin{array}{c}\text { Drainage } \\
\text { area } \\
\left(\mathrm{mi}^{2}\right)\end{array}$ & River mile ${ }^{2}$ \\
\hline 01451000 & Lehigh River at Walnutport, $\mathrm{Pa}$. & 889 & 33.7 \\
\hline 01451500 & Little Lehigh Creek near Allentown, $\mathrm{Pa}$. & 80.8 & - \\
\hline 01452000 & Jordan Creek at Allentown, $\mathrm{Pa}$. & 75.8 & - \\
\hline 01452500 & Monocacy Creek at Bethlehem, $\mathrm{Pa}$. & 44.5 & - \\
\hline 01453000 & Lehigh River at Bethlehem, $\mathrm{Pa}$. & ${ }^{4} 1,279$ & 11.8 \\
\hline 01454700 & Lehigh River at Glendon, Pa. & 1,359 & 2.3 \\
\hline 01457000 & Musconetong River near Bloomsbury, N.J. & 141 & - \\
\hline 01459500 & Tohickon Creek near Pipersville, Pa. & 97.4 & - \\
\hline 01463500 & Delaware River at Trenton, N.J. & 6,780 & 134.4 \\
\hline 01468500 & Schuylkill River at Landingville, $\mathrm{Pa}$. & 133 & 123.8 \\
\hline 01469500 & Little Schuylkill River at Tamaqua, Pa. & 42.9 & - \\
\hline 01470500 & Schuylkill River at Berne, $\mathrm{Pa}$. & 355 & 95.5 \\
\hline 01470756 & Maiden Creek at Virginville, $\mathrm{Pa}$. & 159 & - \\
\hline 01471000 & Tulpehocken Creek near Reading, Pa. & 211 & - \\
\hline 01471510 & Schuylkill River near Reading, $\mathrm{Pa}$. & 880 & 75.7 \\
\hline 01471980 & Manatawny Creek near Pottstown, Pa. & 85.5 & - \\
\hline 01472000 & Schuylkill River at Pottstown, Pa. & 1,147 & 53.7 \\
\hline 01472157 & French Creek near Phoenixville, Pa. & 59.1 & - \\
\hline 01473000 & Perkiomen Creek at Graterford, Pa. & 279 & - \\
\hline 01473120 & Skippack Creek near Collegeville, Pa. & 53.7 & - \\
\hline 01474000 & Wissahickon Creek at mouth, Philadelphia, Pa. & 64.0 & - \\
\hline 01474500 & Schuylkill River at Philadelphia, Pa. & 1,893 & 8.7 \\
\hline 01480617 & West Branch Brandywine Creek at Modena, Pa. & 55.0 & 533.4 \\
\hline 01480870 & East Branch Brandywine Creek below Downingtown, $\mathrm{Pa}$. & 89.9 & $5_{25.1}$ \\
\hline 01481000 & Brandywine Creek at Chadds Ford, Pa. & 287 & 14.8 \\
\hline 01481500 & Brandywine Creek at Wilmington, Del. & 314 & 4.5 \\
\hline
\end{tabular}

1 U.S. Geological Survey downstream-order gaging-station number.

${ }^{2}$ Mileages are from listings prepared by the Delaware River Basin Commission, May 1967, and U.S. Geological Survey topographic maps. No mileage shown for gaging stations that are not in a modeled stream reach.

${ }^{3}$ From mouth of Lackawaxen River.

4 Includes that of Monocacy Creek.

${ }^{5}$ From mouth of Brandywine Creek. 


\section{CAUBRATON OF THE MODELS BY STREAMFLOW SIMULATION}

The HYDR section of the RCHRES module was calibrated to simulate available records of daily streamflows for calendar years 1979-83 at the downstream ends of the selected reaches (table 2). Calibration for successive reaches was achieved by adding hydrographs of gaged inflows to estimated hydrographs for ungaged, contributory drainage areas and then routing the composite hydrograph through the reach. The simulated outflow hydrograph provided the primary input for the successive, downstream reach. Estimates of the functional relation between reach volume and outflow rate are contained in the F-tables, which constitute the other necessary input data for routing. These relations can be adjusted by successive approximations until the simulated outflow suitably replicates the observed outflow. Adjustment of the volume-outflow relation often is complicated by the need to estimate a large part of the tributary inflow to the reach. These estimates of inflows usually are obtained by applying selected weighting factors to one or more hydrographs of gaged flows for the modeled stream, for influent streams, or for other small streams in and near the study basin. In general, as the proportion of estimated inflow increases, the accuracy of the simulation decreases throughout the range of observed outflows. Owing to errors and timing differences in the input hydrographs, exact duplication of the daily streamflow record observed at the downstream end of a reach is seldom possible. Additionally, results of the simulation are affected by the selected value of the routing factor KS. RCHRES does not contain an automated optimization routine for the volume-outflow relation or KS. Verification of the calibration, by repeating the simulation with a wide range of daily streamflows for another period, will usually disclose any calibration errors of significance.

\section{E-Table Generation and Refinement}

A series of trial-and-error approximations were made to obtain flow-calibrated relations between reach volumes and statistical outflow rates. F-tables are satisfactorily calibrated when the shapes of the simulated and observed outflow hydrographs closely match. A reliable approximation of the volumeoutflow relation can be obtained only where the daily volumes of inflow, which the program requires be inserted at the head of each reach, closely match outflow volumes throughout the observed range of streamflows. For this reason, the streamflow data available for the estimation of ungaged inflows have a strong effect on the accuracy of the simulation.

A first approximation of the volume-outflow relation for each modeled reach was calculated from reach-length and cross-sectional data. Reach lengths (table 2) were measured on 7 1/2-minute topographic maps (U.S. Geological Survey, 1989; 1990). The cross-sectional data were obtained from several sources-an unpublished computer file of step-backwater data for the Delaware River below Tocks Island, prepared by the U.S. Army Corps of Engineers, Philadelphia; channel-geometry data developed for the preparation of Flood Insurance Studies by various contractors to the Federal Emergency Management Agency; and, in the absence of surveyed cross-sectional data, the topographic maps.

Two channel cross sections, one near each end of the reach, usually were sufficient to calculate suitable first estimates of reach volumes for each of the selected statistical outflow rates. Broad floodplains in a reach, such as those associated with braided and anabranched channels, often required a third representative cross section to provide sufficient volume to compute the first simulation. In retrospect, a considerable savings in effort could have been achieved by the use of three or four widely spaced cross sections for each of the longest streams to develop generalized, stream-specific volume-discharge relations for the selected statistical measures of flow. Initial volume-outflow relations could have been satisfactorily interpolated for the various reaches in the Delaware, Lehigh, and Schuylkill Rivers from such relations.

The first step in the calibration process was to estimate inflows from daily streamflow data for selected gaging stations and to test these estimates by means of simulations with HYDR until the routed volumes matched observed outflow volumes to within 10 percent. Next, the volume-outflow relations were graphically smoothed to remove any irregularities inadvertently introduced by use of atypical cross sections. Additional adjustments of the volume-outflow relations, to provide more or less storage for selected ranges of streamflow, were needed to differentially shift timing within the simulated hydrographs. All but 2 of the 31 original volume-outflow relations required some modification. 
Adjustments to the slopes of some of these relations resulted in both positive and negative changes in reach volumes. The largest adjustment to a particular volume was 220 percent; however, most volumes were changed by less than 50 percent in this calibration. For some reaches, no configuration of the volumeoutflow relation could be devised to provide accurate timing of the simulated hydrograph throughout its entire range in discharge. In most such cases, a reselection of streamflow records for the estimation of ungaged inflows led to an improved simulation.

Root mean square errors, bias, and standard errors of estimate for simulated daily discharges were the principal statistical measures used to evaluate the quality of the streamflow simulations for the calibration period.

The calibrated volumes and their associated statistical discharge values (outflow rates) are shown by reach in table 4. Data in the first two and last columns of this table-depth, area, and traveltime-are not required for flow routing. Stream depth, which was determined from gaging-station data and synthetically derived stage-discharge relations for the downstream end of each reach, can be used in conjunction with other data inserted in the user-control input to compute selected hydraulic parameters. Similar use can be made of surface-area data. Surface areas were calculated for the F-tables from the crosssectional data used to make the initial estimates of the volume-outflow relations. These estimates of surface areas in the reaches could be used in a HSPF flow-generation model in which precipitation and evaporation on the stream surface are taken into account. Approximate traveltimes were calculated by dividing reach volumes by corresponding discharges. These are the theoretical average traveltimes for the selected statistical discharges of the volume-outflow relations. 
Table 4. F-tables for modeled stream reaches in the Delaware River Basin [Locations of reaches are shown in figure 3.]

\begin{tabular}{ccccc}
\hline $\begin{array}{c}\text { Depth } \\
\text { (feet) }\end{array}$ & $\begin{array}{c}\text { Area }^{2} \\
\text { (acres) }\end{array}$ & $\begin{array}{c}\text { Volume }^{3} \\
\text { (acre feet) }\end{array}$ & $\begin{array}{c}\text { Discharge } \\
\text { (cubic feet } \\
\text { per second) }\end{array}$ & $\begin{array}{c}\text { Travel time } \\
\text { (hours) }\end{array}$ \\
\hline Reach 1 & & & & \\
1.1 & 320 & 970 & 0 & - \\
2.1 & 330 & 1,150 & 35 & 398 \\
2.5 & 335 & 1,250 & 81 & 187 \\
2.8 & 340 & 1,410 & 145 & 118 \\
4.5 & 420 & 2,040 & 910 & 27.1 \\
9.1 & 580 & 4,410 & 5,900 & 9.0 \\
13.1 & 700 & 6,160 & 13,000 & 5.7 \\
17.1 & 940 & 8,550 & 24,000 & 4.3
\end{tabular}

Reach 2

$\begin{array}{rrrrr}.1 & 110 & 340 & 0 & - \\ .9 & 160 & 450 & 107 & 50.9 \\ 1.4 & 220 & 520 & 230 & 27.4 \\ 2.2 & 245 & 660 & 660 & 12.1 \\ 5.2 & 265 & 1,060 & 2,370 & 5.4 \\ 9.4 & 315 & 3,000 & 19,300 & 1.9 \\ 12.1 & 385 & 4,000 & 31,400 & 1.5 \\ 14.2 & 520 & 4,700 & 41,000 & 1.4\end{array}$

Reach 3

$\begin{array}{rrrrr}.0 & 50 & 15 & 0 & - \\ 2.1 & 120 & 55 & 38 & 17.5 \\ 2.6 & 135 & 92 & 116 & 9.6 \\ 3.7 & 183 & 190 & 511 & 4.5 \\ 5.5 & 205 & 370 & 1,830 & 2.4 \\ 9.5 & 245 & 770 & 7,300 & 1.3 \\ 14.2 & 300 & 1,300 & 17,800 & .9 \\ 19.5 & 320 & 1,960 & 35,000 & .7\end{array}$

Reach 4

$\begin{array}{rrrrr}.0 & 300 & 130 & 0 & - \\ 1.2 & 840 & 1,460 & 339 & 28.6 \\ 1.7 & 1,320 & 2,270 & 803 & 19.9 \\ 2.3 & 1,750 & 3,500 & 1,850 & 14.8 \\ 3.6 & 1,830 & 6,900 & 6,190 & 9.4 \\ 8.9 & 2,010 & 19,200 & 37,340 & 5.0 \\ 13.0 & 2,120 & 30,000 & 74,160 & 4.0 \\ 18.2 & 2,230 & 42,000 & 127,000 & 3.3\end{array}$

Reach 5

$\begin{array}{rrrrr}3.0 & 300 & 50 & 0 & - \\ 5.3 & 750 & 720 & 371 & 23.5 \\ 6.0 & 930 & 1,120 & 816 & 15.1 \\ 6.9 & 1,160 & 1,860 & 1,900 & 10.8 \\ 9.2 & 1,240 & 4,050 & 6,850 & 6.2 \\ 17.0 & 1,410 & 13,100 & 42,800 & 3.0 \\ 23.7 & 1,520 & 20,500 & 85,000 & 2.3 \\ 32.6 & 1,760 & 29,500 & 152,000 & 1.9\end{array}$


Table 4. F-tables for modeled stream reaches in the Delaware River Basin--Continued [Locations of reaches are shown in figure 3.]

\begin{tabular}{ccccc}
\hline $\begin{array}{c}\text { Depth } \\
\text { (feet) }\end{array}$ & $\begin{array}{c}\text { Area }^{2} \\
\text { (acres) }\end{array}$ & $\begin{array}{c}\text { Volume } \\
\text { (acre feet) }\end{array}$ & $\begin{array}{c}\text { Discharge } \\
\text { (cubic feet } \\
\text { per second) }\end{array}$ & $\begin{array}{c}\text { Travel time } \\
\text { (hours) }\end{array}$ \\
\hline Reach 6 & & & & \\
1.0 & 105 & 70 & 0 & - \\
1.8 & 155 & 175 & 17 & 125 \\
2.1 & 160 & 210 & 51 & 49.8 \\
2.9 & 165 & 320 & 250 & 15.5 \\
4.5 & 175 & 560 & 1,100 & 6.2 \\
8.5 & 200 & 1,150 & 5,800 & 2.4 \\
13.7 & 215 & 1,990 & 16,000 & 1.5 \\
19.1 & 225 & 2,970 & 30,700 & 1.2
\end{tabular}

Reach 7

$\begin{array}{rrrrr}.0 & 150 & 50 & 0 & - \\ .7 & 240 & 211 & 17 & 150 \\ .9 & 265 & 273 & 51 & 64.8 \\ 1.6 & 290 & 483 & 250 & 23.4 \\ 2.9 & 325 & 915 & 1,110 & 10.0 \\ 6.2 & 365 & 2,120 & 5,800 & 4.4 \\ 10.4 & 395 & 3,860 & 16,000 & 2.9 \\ 14.5 & 415 & 5,720 & 30,700 & 2.3\end{array}$

Reach 8

$\begin{array}{rrrrr}1.0 & 820 & 800 & 0 & - \\ 3.2 & 1,300 & 3,700 & 442 & 101 \\ 3.9 & 1,380 & 4,700 & 1,100 & 51.7 \\ 5.1 & 1,440 & 6,700 & 3,400 & 23.8 \\ 7.3 & 1,550 & 10,800 & 12,000 & 10.9 \\ 13.3 & 1,750 & 25,500 & 55,000 & 5.6 \\ 17.6 & 1,840 & 38,000 & 102,000 & 4.5 \\ 24.0 & 2,070 & 58,000 & 192,000 & 3.7\end{array}$

Reach 9

$0.0 \quad 13$

$\begin{array}{lll}.7 & 27 & 14\end{array}$

$\begin{array}{lll}1.0 & 30 & 20\end{array}$

$\begin{array}{lll}1.6 & 39 & 39\end{array}$

$\begin{array}{lll}3.7 & 42 & 87\end{array}$

$4.6 \quad 54 \quad 210$

$6.6 \quad 74 \quad 340$

$9.6 \quad 92 \quad 610$

Reach 10

$\begin{array}{rrrrc}.6 & 120 & 70 & 0 & - \\ 1.9 & 245 & 260 & 52 & 60.5 \\ 2.2 & 260 & 315 & 106 & 36.0 \\ 2.7 & 300 & 460 & 269 & 20.7 \\ 3.7 & 315 & 820 & 904 & 11.0 \\ 6.6 & 405 & 1,770 & 5,000 & 4.3 \\ 9.1 & 530 & 2,760 & 10,200 & 3.3 \\ 11.5 & 770 & 4,800 & 21,900 & 2.7\end{array}$


Table 4. F-tables for modeled stream reaches in the Delaware River Basin--Continued [Locations of reaches are shown in figure 3.]

\begin{tabular}{|c|c|c|c|c|}
\hline $\begin{array}{c}\text { Depth }{ }^{1} \\
\text { (feet) }\end{array}$ & $\begin{array}{c}\text { Area }^{2} \\
\text { (acres) }\end{array}$ & $\begin{array}{l}\text { Volume }^{3} \\
\text { (acre feet) }\end{array}$ & $\begin{array}{l}\text { Discharge } 4 \\
\text { (cubic feet } \\
\text { per second) }\end{array}$ & $\begin{array}{c}\text { Travel time } \\
\text { (hours) }\end{array}$ \\
\hline \multicolumn{5}{|l|}{ Reach 11} \\
\hline .2 & 20 & 60 & 0 & - \\
\hline 1.2 & 150 & 250 & 60 & 50.4 \\
\hline 1.5 & 155 & 300 & 120 & 30.2 \\
\hline 2.1 & 160 & 380 & 300 & 15.3 \\
\hline 3.5 & 165 & 550 & 1,000 & 6.7 \\
\hline 9.9 & 180 & 1,500 & 5,450 & 3.3 \\
\hline 15.8 & 185 & 2,800 & 10,710 & 3.2 \\
\hline 23.7 & 345 & 5,600 & 22,500 & 3.0 \\
\hline \multicolumn{5}{|l|}{ Reach 12} \\
\hline 4.3 & 480 & 700 & 0 & - \\
\hline 6.0 & 565 & 2,010 & 669 & 36.4 \\
\hline 6.6 & 575 & 2,370 & 1,400 & 20.5 \\
\hline 8.0 & 590 & 3,110 & 4,000 & 9.4 \\
\hline 11.0 & 655 & 4,740 & 13,400 & 4.3 \\
\hline 18.9 & 730 & 9,520 & 58,000 & 2.0 \\
\hline 24.4 & 765 & 13,180 & 106,000 & 1.5 \\
\hline 33.4 & 825 & 19,300 & 204,000 & 1.1 \\
\hline \multicolumn{5}{|l|}{ Reach 13} \\
\hline 3.3 & 1,200 & 1,500 & 0 & - \\
\hline 5.1 & 1,630 & 6,600 & 760 & 105 \\
\hline 5.5 & 1,840 & 7,700 & 1,520 & 61.3 \\
\hline 6.7 & 2,100 & 10,700 & 4,550 & 28.5 \\
\hline 9.3 & 2,450 & 17,600 & 14,900 & 14.3 \\
\hline 16.3 & 2,890 & 40,000 & 61,000 & 7.9 \\
\hline 24.4 & 3,550 & 59,000 & 110,000 & 6.5 \\
\hline 34.4 & 4,090 & 92,000 & 212,000 & 5.3 \\
\hline \multicolumn{5}{|l|}{ Reach 14} \\
\hline 14.0 & 770 & 3,500 & 0 & - \\
\hline 15.1 & 1,010 & 4,430 & 915 & 58.6 \\
\hline 16.6 & 1,140 & 5,080 & 1,720 & 35.7 \\
\hline 17.0 & 1,330 & 6,770 & 5,500 & 14.9 \\
\hline 20.0 & 1,520 & 10,600 & 17,400 & 7.4 \\
\hline 26.8 & 1,680 & 22,100 & 66,300 & 4.0 \\
\hline 32.0 & 2,020 & 35,100 & 119,000 & 3.6 \\
\hline 40.2 & 2,620 & 56,100 & 235,000 & 2.9 \\
\hline \multicolumn{5}{|l|}{ Reach 15} \\
\hline 7.5 & 470 & 2,640 & 0 & - \\
\hline 11.5 & 555 & 3,530 & 1,140 & 37.5 \\
\hline 12.5 & 605 & 3,920 & 2,125 & 22.3 \\
\hline 15.4 & 735 & 5,120 & 6,550 & 9.5 \\
\hline 20.6 & 910 & 8,180 & 20,230 & 4.9 \\
\hline 31.4 & 990 & 16,900 & 67,000 & 3.1 \\
\hline 39.7 & 1,000 & 23,000 & 120,000 & 2.3 \\
\hline 53.7 & 1,420 & 35,000 & 238,000 & 1.8 \\
\hline
\end{tabular}


Table 4. F-tables for modeled stream reaches in the Delaware River Basin--Continued [Locations of reaches are shown in figure 3.]

\begin{tabular}{|c|c|c|c|c|}
\hline $\begin{array}{c}\text { Depth }{ }^{1} \\
\text { (feet) }\end{array}$ & $\begin{array}{c}\text { Area }^{2} \\
\text { (acres) }\end{array}$ & $\begin{array}{c}\text { Volume }^{3} \\
\text { (acre feet) }\end{array}$ & $\begin{array}{l}\text { Discharge } \\
\text { (cubic feet } \\
\text { per second) }\end{array}$ & $\begin{array}{l}\text { Travel time } \\
\text { (hours) }\end{array}$ \\
\hline \multicolumn{5}{|l|}{ Reach 16} \\
\hline .0 & 445 & 200 & 0 & - \\
\hline .6 & 495 & 800 & 107 & 90.5 \\
\hline 1.2 & 510 & 1,200 & 270 & 53.8 \\
\hline 2.0 & 530 & 1,830 & 720 & 30.8 \\
\hline 3.3 & 1,035 & 3,000 & 2,025 & 17.9 \\
\hline 7.6 & 1,145 & 8,000 & 11,300 & 8.6 \\
\hline 11.0 & 1,360 & 12,000 & 20,500 & 7.1 \\
\hline 18.7 & 1,690 & 21,000 & 38,500 & 6.6 \\
\hline \multicolumn{5}{|l|}{ Reach 17} \\
\hline 0.0 & 35 & 50 & 0 & - \\
\hline 1.0 & 66 & 95 & 160 & 7.2 \\
\hline 1.6 & 85 & 140 & 420 & 4.0 \\
\hline 2.2 & 87 & 210 & 1,080 & 2.4 \\
\hline 3.1 & 89 & 340 & 3,100 & 1.3 \\
\hline 7.1 & 130 & 900 & 16,700 & .7 \\
\hline 9.9 & 150 & 1,380 & 30,000 & .6 \\
\hline 14.1 & 215 & 2,350 & 55,000 & .5 \\
\hline \multicolumn{5}{|l|}{ Reach 18} \\
\hline .0 & 450 & 300 & 0 & - \\
\hline 1.0 & 620 & 450 & 285 & 19.1 \\
\hline 1.3 & 910 & 800 & 580 & 16.7 \\
\hline 2.1 & 940 & 1,450 & 1,600 & 11.0 \\
\hline 3.6 & 1,010 & 2,450 & 4,500 & 6.6 \\
\hline 10.5 & 1,110 & 8,060 & 24,300 & 4.0 \\
\hline 15.6 & 1,180 & 11,900 & 44,000 & 3.3 \\
\hline 25.7 & 1,860 & 23,360 & 97,000 & 2.9 \\
\hline \multicolumn{5}{|l|}{ Reach 19} \\
\hline .0 & 115 & 70 & 0 & - \\
\hline 3.4 & 320 & 590 & 345 & 20.7 \\
\hline 3.8 & 340 & 720 & 625 & 13.9 \\
\hline 4.8 & 360 & 1,080 & 1,700 & 7.7 \\
\hline 6.6 & 400 & 1,830 & 4,750 & 4.7 \\
\hline 13.6 & 500 & 4,900 & 26,000 & 2.3 \\
\hline 19.9 & 725 & 7,600 & 47,000 & 2.0 \\
\hline 29.1 & 1,130 & 13,400 & 103,000 & 1.6 \\
\hline \multicolumn{5}{|l|}{ Reach 20} \\
\hline 12.0 & 180 & 820 & 0 & - \\
\hline 13.9 & 220 & 1,430 & 1,340 & 12.9 \\
\hline 14.6 & 300 & 1,600 & 2,500 & 7.7 \\
\hline 16.4 & 420 & 2,350 & 7,600 & 3.7 \\
\hline 20.5 & 515 & 4,480 & 23,800 & 2.3 \\
\hline 29.3 & 595 & 9,330 & 75,000 & 1.5 \\
\hline 36.3 & 620 & 12,800 & 137,000 & 1.1 \\
\hline 47.2 & 820 & 20,900 & 277,000 & .9 \\
\hline
\end{tabular}


Table 4. F-tables for modeled stream reaches in the Delaware River Basin--Continued [Locations of reaches are shown in figure 3.]

\begin{tabular}{|c|c|c|c|c|}
\hline $\begin{array}{r}\text { Depth }{ }^{1} \\
\text { (feet) }\end{array}$ & $\begin{array}{c}\text { Area }^{2} \\
\text { (acres) }\end{array}$ & $\begin{array}{c}\text { Volume }^{3} \\
\text { (acre feet) }\end{array}$ & $\begin{array}{c}\text { Discharge }^{4} \\
\text { (cubic feet } \\
\text { per second) }\end{array}$ & $\begin{array}{l}\text { Travel time } \\
\text { (hours) }\end{array}$ \\
\hline \multicolumn{5}{|l|}{ Reach 21} \\
\hline 3.3 & 2,700 & 5,660 & 0 & - \\
\hline 4.3 & 3,420 & 9,800 & 1,500 & 79.1 \\
\hline 4.8 & 3,770 & 11,240 & 2,750 & 49.5 \\
\hline 6.2 & 4,210 & 17,340 & 8,300 & 25.3 \\
\hline 8.6 & 4,340 & 29,400 & 24,800 & 14.3 \\
\hline 12.9 & 4,490 & 52,400 & 77,000 & 8.2 \\
\hline 17.2 & 4,630 & 68,930 & 142,000 & 5.9 \\
\hline 23.5 & 5,230 & 106,700 & 283,000 & 4.6 \\
\hline \multicolumn{5}{|l|}{ Reach 22} \\
\hline 4.3 & 130 & 100 & 0 & - \\
\hline 4.6 & 165 & 200 & 77 & 31.4 \\
\hline 4.9 & 175 & 230 & 144 & 19.3 \\
\hline 5.8 & 210 & 310 & 412 & 9.1 \\
\hline 7.5 & 290 & 490 & 1,340 & 4.4 \\
\hline 13.9 & 445 & 1,600 & 9,860 & 2.0 \\
\hline 18.5 & 560 & 3,300 & 21,000 & 1.9 \\
\hline 24.7 & 650 & 6,800 & 41,200 & 2.0 \\
\hline \multicolumn{5}{|l|}{ Reach 23} \\
\hline .00 & 80 & 80 & 0 & - \\
\hline .23 & 90 & 130 & 80 & 19.7 \\
\hline .38 & 94 & 140 & 150 & 11.3 \\
\hline .82 & 101 & 180 & 430 & 5.1 \\
\hline 1.75 & 110 & 270 & 1,400 & 2.3 \\
\hline 5.94 & 150 & 800 & 10,300 & .9 \\
\hline 9.36 & 330 & 1,300 & 21,800 & .7 \\
\hline 14.44 & 395 & 2,100 & 42,200 & .6 \\
\hline \multicolumn{5}{|l|}{ Reach 24} \\
\hline .00 & 530 & 600 & 0 & - \\
\hline .20 & 560 & 780 & 160 & 59.0 \\
\hline .38 & 575 & 830 & 300 & 33.5 \\
\hline 1.06 & 605 & 1,050 & 940 & 13.5 \\
\hline 2.75 & 615 & 1,900 & 3,200 & 7.2 \\
\hline 9.73 & 660 & 5,400 & 16,500 & 4.0 \\
\hline 14.18 & 1,230 & 8,400 & 28,500 & 3.6 \\
\hline 24.35 & 1,410 & 16,000 & 60,000 & 3.2 \\
\hline \multicolumn{5}{|c|}{ Reach 25} \\
\hline 0.00 & 700 & 900 & 0 & - \\
\hline .85 & 790 & 1,400 & 250 & 67.8 \\
\hline 1.19 & 800 & 1,500 & 440 & 41.3 \\
\hline 2.07 & 825 & 2,000 & 1,200 & 20.2 \\
\hline 4.00 & 920 & 3,300 & 3,700 & 10.8 \\
\hline 10.8 & 1,265 & 9,400 & 19,800 & 5.7 \\
\hline 15.0 & 1,735 & 13,000 & 32,500 & 4.8 \\
\hline 25.0 & 2,340 & 24,000 & 74,000 & 3.9 \\
\hline
\end{tabular}


Table 4. F-tables for modeled stream reaches in the Delaware River Basin--Continued [Locations of reaches are shown in figure 3.]

\begin{tabular}{|c|c|c|c|c|}
\hline $\begin{array}{c}\text { Depth } 1 \\
\text { (feet) }\end{array}$ & $\begin{array}{l}\text { Area }^{2} \\
\text { (acres) }\end{array}$ & $\begin{array}{l}\text { Volume }^{3} \\
\text { (acre feet) }\end{array}$ & $\begin{array}{l}\text { Discharge }^{4} \\
\text { (cubic feet } \\
\text { per second) }\end{array}$ & $\begin{array}{c}\text { Travel time } \\
\text { (hours) }\end{array}$ \\
\hline \multicolumn{5}{|l|}{ Reach 26} \\
\hline 6.7 & 800 & 900 & 0 & - \\
\hline 7.5 & 1,000 & 2,500 & 383 & 79.0 \\
\hline 8.7 & 1,035 & 3,600 & 685 & 63.6 \\
\hline 9.7 & 1,060 & 5,100 & 1,880 & 32.8 \\
\hline 11.0 & 1,350 & 8,000 & 5,850 & 16.5 \\
\hline 17.9 & 2,900 & 18,000 & 32,800 & 6.6 \\
\hline 25.1 & 3,980 & 26,000 & 65,000 & 4.8 \\
\hline 34.2 & 5,150 & 36,000 & 117,000 & 3.7 \\
\hline \multicolumn{5}{|l|}{ Reach 27} \\
\hline .00 & 1,000 & 900 & 0 & - \\
\hline .15 & 1,450 & 2,500 & 669 & 7 \\
\hline .43 & 1,465 & 3,600 & 6340 & 7 \\
\hline .80 & 1,530 & 5,900 & ${ }^{6} 1,500$ & 7 \\
\hline 1.7 & 1,800 & 10,200 & 5,600 & 22.0 \\
\hline 5.1 & 2,740 & 26,000 & 36,400 & 8.6 \\
\hline 7.3 & 3,660 & 37,000 & 69,500 & 6.4 \\
\hline 11.1 & 4,300 & 56,000 & 137,000 & 4.7 \\
\hline
\end{tabular}

Reach 28

$\begin{array}{rrrrr}.1 & 48 & 11 & 0 & - \\ .5 & 139 & 51 & 44 & 14.0 \\ .6 & 140 & 63 & 71 & 10.7 \\ .8 & 143 & 90 & 162 & 6.7 \\ 1.2 & 145 & 134 & 394 & 4.1 \\ 4.8 & 180 & 717 & 5,820 & 1.5 \\ 7.4 & 780 & 1,810 & 11,570 & 1.9 \\ 11.7 & 945 & 4,925 & 21,500 & 2.8\end{array}$

Reach 29

$\begin{array}{rrrrr}1.4 & 74 & 64 & 0 & - \\ 1.7 & 75 & 92 & 34 & 32.7 \\ 1.8 & 76 & 101 & 56 & 21.8 \\ 2.2 & 77 & 132 & 142 & 11.2 \\ 2.9 & 79 & 187 & 410 & 5.5 \\ 7.3 & 88 & 548 & 3,020 & 2.2 \\ 12.0 & 145 & 1,030 & 6,990 & 1.8 \\ 14.8 & 350 & 1,810 & 12,900 & 1.7\end{array}$

Reach 30

$\begin{array}{rrrrr}1.0 & 65 & 36 & 0 & - \\ 1.7 & 85 & 112 & 70 & 19.4 \\ 1.9 & 89 & 127 & 120 & 12.8 \\ 2.3 & 101 & 160 & 283 & 6.8 \\ 3.3 & 110 & 250 & 727 & 4.2 \\ 10.6 & 245 & 1,420 & 6,780 & 2.5 \\ 13.7 & 560 & 2,650 & 13,000 & 2.5 \\ 17.5 & 650 & 5,400 & 26,100 & 2.5\end{array}$


Table 4. F-tables for modeled stream reaches in the Delaware River Basin--Continued [Locations of reaches are shown in figure 3.]

\begin{tabular}{ccccc}
\hline $\begin{array}{c}\text { Depth } \\
\text { (feet) }\end{array}$ & $\begin{array}{c}\text { Area }^{2} \\
\text { (acres) }\end{array}$ & $\begin{array}{c}\text { Volume }^{3} \\
\text { (acre feet) }\end{array}$ & $\begin{array}{c}\text { Discharge } \\
\text { (cubic feet }_{\text {per second) }}\end{array}$ & $\begin{array}{c}\text { Travel time }^{5} \\
\text { (hours) }\end{array}$ \\
\hline Reach 31 & & & & \\
4.7 & 215 & 565 & 0 & - \\
5.7 & 250 & 823 & 76 & 131 \\
5.9 & 260 & 869 & 132 & 79.7 \\
6.3 & 282 & 980 & 331 & 35.8 \\
7.1 & 292 & 1,200 & 893 & 16.3 \\
11.5 & 550 & 3,100 & 7,600 & 4.9 \\
15.1 & 955 & 5,640 & 17,100 & 4.0 \\
19.2 & 1,220 & 9,990 & 32,200 & 3.8 \\
\hline
\end{tabular}

${ }^{1}$ Average depth of flow at end of reach-as derived from discharge rating curves for gaging stations and cross-sectional information for gaging stations and other locations.

${ }^{2}$ Approximate surface area.

${ }^{3}$ Values were determined by trial-and-error modification of initial estimates in the calibration of the flow-routing model to replicate streamflow hydrographs.

${ }^{4}$ Indicated discharges are for the following sequence of statistical flows: zero; 7-day, 10-year low; lower decile; median; upper decile; 2-year flood; 10-year flood; and 100-year flood.

5 Computed by dividing the calibrated volumes by the indicated discharges. Traveltime is not a required input to the RCHRES module of HSPF. Reach lengths are given in table 1.

${ }^{6}$ Flow substantially reduced by withdrawals for the City of Philadelphia.

${ }^{7}$ Cannot be estimated from indicated discharge.

\section{Estimation of Ungaged Inflow}

Streamflow records for gaged tributaries provided a means of accurately estimating a substantial part of the inflow to several reaches; however, for most reaches all or a part of the incremental inflow was estimated from flow records for noninfluent streams. Basin size and proximity to ungaged parts of the watersheds of the modeled streams were the principal measures used in selecting noninfluent streams for which the flow records have transfer value. Initial estimation of the weighting factors to be applied to the daily streamflow records for both influent and noninfluent streams were based on drainage area. Subsequent to the F-table adjustments, which served to match the timing of the simulated hydrographs to that of the observed, simulated discharges were fine-tuned over their ranges of flow in the 5-year calibration period by selective readjustment of weighting factors. These final adjustments to inflow estimates for the individual reaches, as well as minor adjustments to the volume-outflow relations, were made on the basis of multiple-reach simulations, such as those for the Delaware River (table 2). The factors that were calibrated to estimate inflows for the modeled streams are shown in table 5 , by reach number and the gaging-station number of the daily streamflow records to which the factors were applied.

Flow-weighting factors are applied in the EXTERNAL SOURCES block of the user-control input, as shown in the example in table 1. The number of the data set in the WDM file containing the source-flow record and the target-reach number for RCHRES also are indicated in this block. RCHRES sums the inflows to the designated reach for each time step. The accuracy of the simulations was improved by partitioning daily discharges into 6-hour time steps for modeling all 31 reaches. Minor adjustment factors also can be applied in the NETWORK block, which specifies the reach-to-reach routing order for multiplereach modeling. 
Data provided in tables 2-5 were used to construct flow-routing models, similar to that given in table 1, for the Lackawaxen River, Neversink River, Lehigh River, Schuylkill River, and Brandywine Creek (fig. 3). When flow-adjustment factors are used in a multiple-reach model of the Delaware River, care must be taken to ensure that inflows from the modeled tributaries-the Lackawaxen, Neversink, and Lehigh Rivers-are used only once. Furthermore, only that part of the multiplication factors greater than 1.00 for individual reaches (table 5) is applicable for main-stem streamflow records that are intermediate in the multiple reach. For example, when reaches 1-8 are combined into a multiple reach, the multiplication factors for records of main-stem gaging stations downstream of 01417000 and 01425000 are:

$\begin{array}{cc}\text { Gaging-station number } & \text { Multiplication factor } \\ 01417500 & 0.00 \\ 01421000 & .02 \\ 01426500 & .00 \\ 01427510 & .00 \\ 01428500 & .03\end{array}$

\section{Sensitivity Analyses}

Sensitivity tests were used to evaluate the effects of variables in the HYDR section of the RCHRES module on routing results. The model for reach 13 , which covers $30.2 \mathrm{mi}$ of the Delaware River between the Montague and Tocks Island gaging stations, was selected for these tests. A test simulation with a daily time step showed that the adopted convention of 6-hour partitioning of daily discharges provided no improvement for this particular reach; however, significant improvements in simulations were obtained through use of 6-hour time steps for the shortest of the study reaches.

After selection of the flow records and appropriate multiplication factors to calculate input discharges for a reach (table 5), only the values of the routing factor, $\mathrm{KS}$, and the storage volumes in the F-table have significant effects on simulation results. The sensitivity of flow simulations to variations in KS and F-table volumes was evaluated by applying the time-series-comparison analytical option of ANNIE simulation results for three values of KS and three volume distributions. The results of these tests are given in table 6. In this table, $\mathrm{KS}=0.5$ and a volume factor of 1.0 for the F-table represent the calibration values of the tested variables. The standard error of estimate statistics suggest that a $\mathrm{KS}$ value of 0.4 is marginally preferable to the usual value of 0.5 for this reach. A 20-percent reduction or increment to the calibrated volumes of the F-table would have a minor effect on the accuracy of the simulation. The selected distribution of volumes for the F-table of reach 13 (table 4) resulted from a trial-and-error balancing of root mean square errors and standard errors of estimate. 
Table 5. Gaging-station numbers of flow records and multiplication factors used to estimate inflows to the modeled reaches

[Locations of reaches are shown in figure 3]

\begin{tabular}{|c|c|c|c|}
\hline $\begin{array}{l}\text { Reach } \\
\text { number }\end{array}$ & $\begin{array}{l}\text { Gaging-station number } \\
\text { of daily flow record } \\
\text { used for inflow estimate }\end{array}$ & $\begin{array}{l}\text { Multiplication } \\
\text { factor applied to } \\
\text { streamflow record }\end{array}$ & $\begin{array}{l}\text { Percentage } \\
\text { ungaged }^{3}\end{array}$ \\
\hline \multirow[t]{2}{*}{1} & 01417000 & 1.05 & 19 \\
\hline & 01420500 & .26 & \\
\hline \multirow[t]{2}{*}{2} & 01417500 & 1.00 & 11 \\
\hline & 01420500 & 1.30 & \\
\hline \multirow[t]{2}{*}{3} & 01425000 & 1.05 & 23 \\
\hline & 01423000 & .30 & \\
\hline \multirow[t]{4}{*}{4} & 01421000 & 1.02 & 24 \\
\hline & 01426500 & 1.00 & \\
\hline & 01420500 & .84 & \\
\hline & 01423000 & .20 & \\
\hline \multirow[t]{2}{*}{5} & 01427510 & 1.00 & 10 \\
\hline & 01420500 & .50 & \\
\hline \multirow[t]{3}{*}{6} & 01429000 & 1.50 & 57 \\
\hline & 01429500 & 1.50 & \\
\hline & 01439500 & .48 & \\
\hline \multirow[t]{3}{*}{7} & 01431500 & 1.00 & 13 \\
\hline & 01432000 & 1.00 & \\
\hline & 01439500 & .50 & \\
\hline \multirow[t]{6}{*}{8} & 01428500 & 1.03 & 11 \\
\hline & 01420500 & .20 & \\
\hline & 401431500 & 1.00 & \\
\hline & 401432000 & 1.00 & \\
\hline & 401439500 & 1.00 & \\
\hline & 01433500 & 1.15 & \\
\hline \multirow[t]{2}{*}{9} & 01436000 & 1.00 & 19 \\
\hline & 01420500 & .072 & \\
\hline \multirow[t]{2}{*}{10} & 01436500 & 1.00 & 63 \\
\hline & 01420500 & .61 & \\
\hline 11 & 01437500 & 1.10 & 10 \\
\hline \multirow[t]{3}{*}{12} & 01434000 & 1.00 & 3.0 \\
\hline & 01440000 & 1.00 & \\
\hline & ${ }^{5} 01437500$ & 1.10 & \\
\hline \multirow[t]{3}{*}{13} & 01438500 & 1.00 & 4.9 \\
\hline & 01439500 & 2.75 & \\
\hline & 01440000 & 2.75 & \\
\hline \multirow[t]{5}{*}{14} & 01440200 & 1.00 & 4.3 \\
\hline & 01440000 & .50 & \\
\hline & 01442500 & 1.20 & \\
\hline & 01443500 & 1.50 & \\
\hline & 01445500 & 1.60 & \\
\hline \multirow[t]{2}{*}{15} & 01446500 & 1.00 & 3.8 \\
\hline & 01442500 & .70 & \\
\hline 616 & 01447800 & 2.05 & 51 \\
\hline \multirow[t]{3}{*}{${ }^{6} 17$} & 01449000 & 1.14 & 14 \\
\hline & 01449800 & 1.31 & \\
\hline & 01450500 & 1.17 & \\
\hline \multirow[t]{2}{*}{18} & 01451000 & 1.11 & 15 \\
\hline & 01451500 & 1.21 & \\
\hline
\end{tabular}


Table 5. Gaging-station numbers of flow records and multiplication factors used to estimate inflows to the modeled reaches--Continued [Locations of reaches are shown in figure 3]

\begin{tabular}{|c|c|c|c|}
\hline $\begin{array}{l}\text { Reach } \\
\text { number }\end{array}$ & $\begin{array}{l}\text { Gaging-station number } \\
\text { of daily flow record } \\
\text { used for inflow estimate }\end{array}$ & $\begin{array}{l}\text { Multiplication } \\
\text { factor applied to } \\
\text { streamnlow record }\end{array}$ & $\begin{array}{l}\text { Percentage } \\
\text { ungaged }\end{array}$ \\
\hline & 01452000 & 1.20 & \\
\hline & 01452500 & 1.26 & \\
\hline \multirow[t]{2}{*}{19} & 01453000 & 1.09 & 6.0 \\
\hline & 01452500 & 1.20 & \\
\hline \multirow[t]{4}{*}{20} & ${ }^{7} 01446500$ & - & 4.6 \\
\hline & ${ }^{7} 01442500$ & - & \\
\hline & 01454700 & 1.02 & \\
\hline & 01457000 & 2.00 & \\
\hline \multirow[t]{5}{*}{21} & ${ }^{8} 01446500$ & - & 9.6 \\
\hline & ${ }^{8} 01442500$ & - & \\
\hline & ${ }^{8} 01454700$ & - & \\
\hline & ${ }^{8} 01457000$ & - & \\
\hline & 01459500 & 2.00 & \\
\hline 22 & 01468500 & 1.40 & 34 \\
\hline \multirow[t]{2}{*}{23} & ${ }^{9} 01468500$ & 1.07 & 50 \\
\hline & 01469500 & 3.21 & \\
\hline \multirow[t]{3}{*}{24} & 01470500 & 1.27 & 18 \\
\hline & 01470756 & 1.27 & \\
\hline & 01471000 & 1.05 & \\
\hline \multirow[t]{2}{*}{25} & 01471510 & 1.16 & 16 \\
\hline & 01471980 & 1.11 & \\
\hline \multirow[t]{2}{*}{26} & 01472000 & 1.13 & 12 \\
\hline & 01472157 & 1.22 & \\
\hline \multirow[t]{5}{*}{27} & ${ }^{10} 01472000$ & - & 16 \\
\hline & ${ }^{10} 01472157$ & - & \\
\hline & 01473000 & 1.13 & \\
\hline & 01473120 & 1.13 & \\
\hline & 01474000 & 1.05 & \\
\hline 28 & 01480617 & 2.45 & 59 \\
\hline 29 & 01480870 & 1.40 & 28 \\
\hline \multirow[t]{2}{*}{30} & ${ }^{11} 01480617$ & 1.11 & 50 \\
\hline & ${ }^{11} 01480870$ & 1.11 & \\
\hline 31 & 01481000 & 1.09 & 10 \\
\hline
\end{tabular}

${ }^{1}$ Records for calibration period of January 1, 1979, to December 31, 1983, except as noted. Mainstem station, if available, is listed first. See figure 3 for station locations.

2 Factors are for routing individual reaches, except as noted. Each computed inflow of daily mean discharge was applied to four 6-hour time steps per day in the calibration period.

3 Percent of drainage area at the outflow site that is not represented by gaged direct inflow for the calibration period. "Gaged direct inflow" includes those inflows routed through adjoining upstream reaches where outflows are ungaged (see footnotes 7-11).

${ }^{4}$ Includes inflow estimate for reach 7 , for which outflow is ungaged.

5 Inflow estimate for reach 11 , for which outtlow is ungaged.

${ }^{6}$ Calibrated with records for October 1,1982 , to December 31, 1983.

${ }^{7}$ Routed outtlow from reach 15 , which is ungaged.

${ }^{8}$ Routed outtlow from reaches 15 and 20 , which are ungaged.

${ }^{9}$ Routed outtlow from reach 22 , which is ungaged.

${ }^{10}$ Routed outflow from reach 26 , which is ungaged.

${ }^{11}$ Routed outtlow from reaches 28 and 29 , which are ungaged. 
Table 6. Results of sensitivity tests of the routing factor and the storage component of the calibrated F-table for reach 13 on the Delaware River ${ }^{1}$

\begin{tabular}{cccc}
\hline & SEE $^{2}$ & $\begin{array}{c}\mathrm{RMS}^{3} \\
\text { (percent) }\end{array}$ & $\begin{array}{c}\text { Bias } \\
\text { (percent) }\end{array}$ \\
\hline $\mathrm{KS}^{4}$ & & & \\
0.4 & 1289.1 & 1.3 & -0.4 \\
.5 & 1344.9 & 1.3 & -.4 \\
.6 & 1413.6 & 1.3 & -.4 \\
Volume $^{5}$ & & & \\
.8 & 1324.9 & 1.4 & -.4 \\
1.0 & 1344.9 & 1.3 & -.4 \\
1.2 & 1371.2 & 1.2 & -.3 \\
\hline
\end{tabular}

1 Statistical measures of flow-routing results for reach 13 were calculated with time-series-comparison statistical option of the ANNIE program.

${ }^{2}$ Standard error of estimate, which is calculated as the square root of the difference between the squares of the total root mean square errors and the total bias errors for the pairs of observed and simulated daily discharges for 1979-83.

${ }^{3}$ Root mean square error.

${ }^{4}$ Routing factor.

${ }^{5}$ Factor applied to storage volumes of the F-table for reach 13 (table 4). 


\section{EVALUATION OF THE MODELS}

The calibrated models were evaluated by visual and statistical comparative analyses of the simulated and observed (recorded) discharge hydrographs for the 5-year calibration period. Particular attention was given to the utility of the composite model of the Delaware River for replicating low-flow discharges for the Trenton gaging station. This model for the Delaware River was verified by similar comparative analyses of the simulated and observed hydrographs for two 3-month periods outside the calibration period.

\section{Hydroaraph Comparisons}

\section{Timing and Shape}

The developed models produced simulated discharges that, for the most part, closely matched observed daily streamflows. Hydrographs of observed and simulated daily flows for each gaging station on the Delaware River were nearly identical for the entire 5-year calibration period. The accuracy of a flow simulation during low-water periods is of prime concern to water managers who use flow-simulation models, such as HSPF, to estimate basin yields under conditions of extreme drought. Figure 4 shows, by comparative hydrographs of observed and simulated daily discharges for the 3 months of lowest flows in the 5-year calibration period, how well the calibrated model for reaches 1-21 replicated the observed-flow record. At the Trenton stream-gaging station, as well as for other gaged sites on the Delaware River, the timing of simulated peaks and troughs matched the observed hydrograph to within 1 day in nearly all cases. The simulated hydrograph tends to lag the observed, owing to the model requirement that all inflows be inserted at the upstream ends of reaches. Timing errors for the modeled tributaries of the Delaware River were all less than 2 days, and were typically less than 1 day.

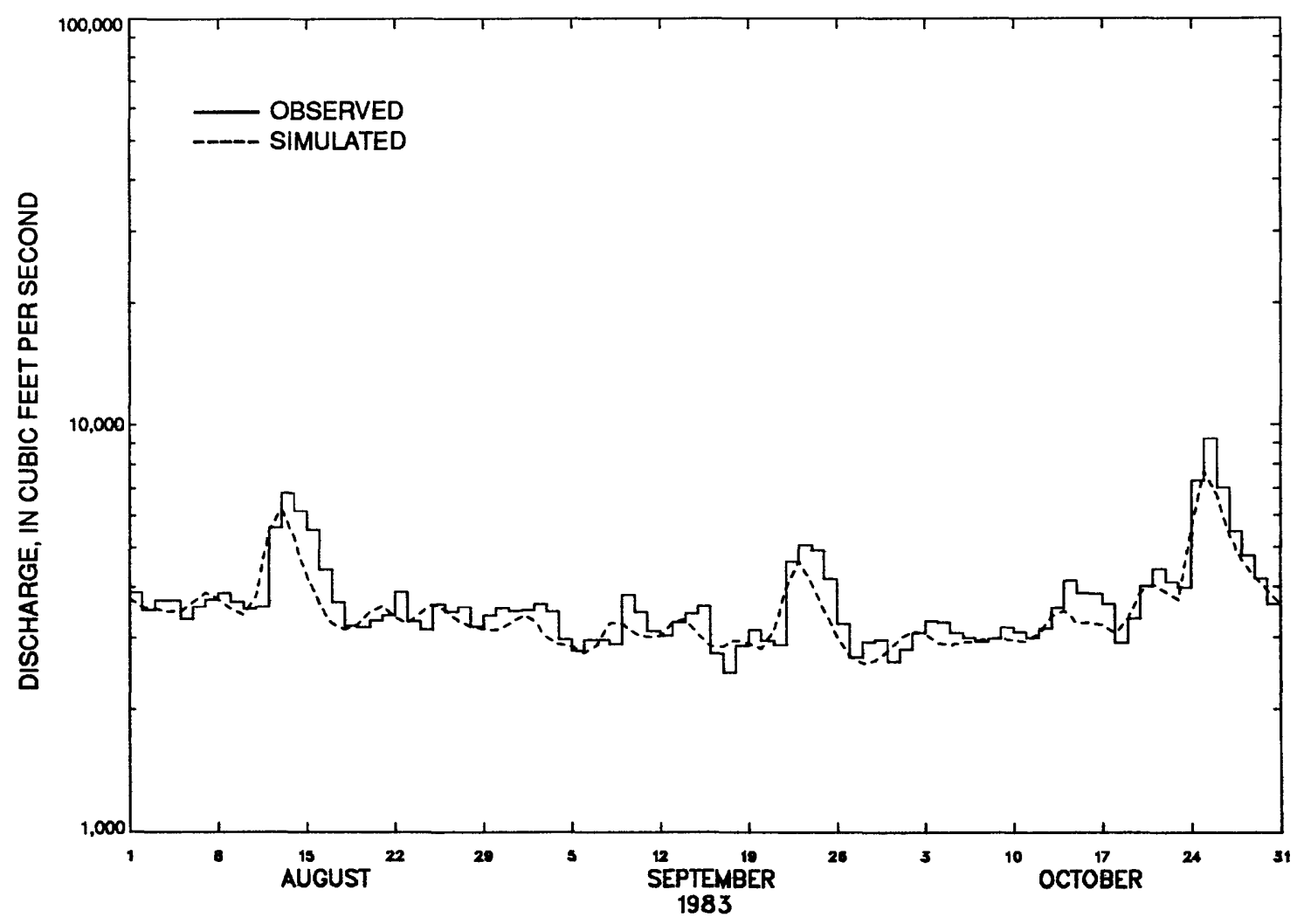

Figure 4. Hydrographs of observed and simulated daily discharges for a 3-month low-flow period, Delaware River at Trenton, N.J. 


\section{Volume}

Statistical evaluations were made of simulated volumes of streamflows for gaging stations at the downstream ends of the reaches. Table 7 presents a summary of root mean square errors and bias, as percentage of total flow during the 5-year calibration period, for these reaches. The data in table 7 were developed from analyses of a 34-class partition of the range of flows at the downstream gaging station of each indicated reach segment. Inspection of the root mean square error and bias for each flow class disclosed that the greatest errors in the simulations were in the upper and lower 2 percentiles of flow, that is, at extreme peaks and troughs. Errors were generally uniformly distributed for the other 96 percent of simulated flows, but more so for gaging stations on the Delaware River than for gaging stations on the modeled tributaries. The poorest simulations are those for the Lackawaxen and Neversink Rivers, for which large fractions of the inflows were estimated (table 5). Furthermore, flow sequences on both of these streams are greatly altered by regulation and diversion.

Table 7. Summary of routing-model errors for the calibration period 1979-83

\begin{tabular}{lcccc}
\hline Stream & $\begin{array}{c}\text { Reach } \\
\text { number }\end{array}$ & $\begin{array}{c}\text { Downstream } \\
\text { gaging station } \\
\text { number }\end{array}$ & $\begin{array}{c}\text { Root mean } \\
\text { square error } \\
\text { (percent) }\end{array}$ & $\begin{array}{c}\text { Bias } \\
\text { (percent) }\end{array}$ \\
\hline Delaware River & 1 & 01417500 & 7.4 & 0.9 \\
& 2 & 01421000 & 1.5 & 1.0 \\
& 3 & 01426500 & 9.4 & .4 \\
& 4 & 01427510 & 5.4 & .6 \\
& 5 & 01428500 & 1.5 & 1.0 \\
& $1-8$ & 01434000 & 2.9 & .3 \\
& 12 & 01434000 & 4.1 & .6 \\
& 13 & 01438500 & .4 & -1.3 \\
& 14 & 01440200 & 1.3 & -.4 \\
Lackawaxen River & $15,20-21$ & 01446500 & .8 & -.2 \\
Neversink River & $1-21$ & 01463500 & 1.0 & .0 \\
Lehigh River & $6-7$ & 01463500 & 1.2 & -1.6 \\
Schuylkill River & $9-10$ & 01431500 & 13.1 & 1.8 \\
Brandywine Creek & $16-19$ & 01437500 & 30.0 & 4.8 \\
\hline
\end{tabular}

${ }^{1}$ Routing-model errors not shown for gaging station 01474500 at Philadelphia, owing to a large reduction in streamflows caused by diversions. 


\section{Duration-of-Flow Comporisons}

Comparative duration curves (cumulative-frequency distributions) were prepared from the 34-class partitions of observed and simulated streamflows for each gaging station that is located at the downstream end of a study reach. These curves aided in calibrating the weighting factors that were applied to various flow records to estimate ungaged inflows (table 5). Figure 5 shows observed and simulated flow-duration curves for the gaging station on the Delaware River at Trenton, N.J. The simulated-flow curve is the result of the calibrated model for reaches 1-21, as presented in table 1 . This illustration typifies the close match between observed and simulated flow-duration curves for each gaged reach on the main stem of the Delaware River, as well as for those on the Lehigh River, the Schuylkill River, and Brandywine Creek. The root mean square error data of table 7 provides a relative index to the "fit" of the simulated-flow curves for these reaches.

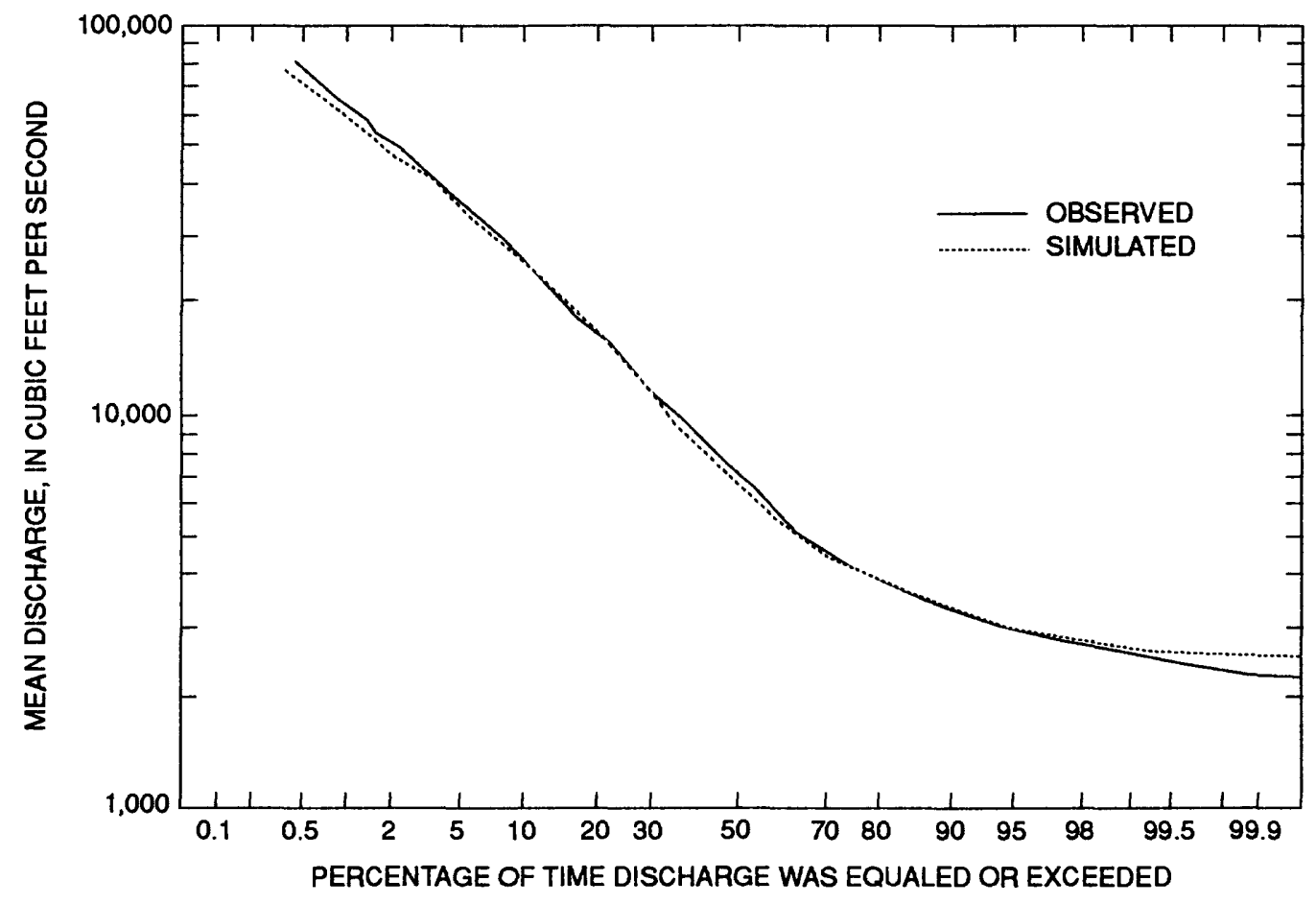

Figure 5. Cumulative-frequency distributions of observed and simulated discharge of Delaware River at Trenton, N.J., for the calibration period, 1979-83. 


\section{Verification of Models.}

Verification of the calibrated HSPF routing model for the Delaware River (table 1) was performed by simulation of daily streamflows for an extreme low-water period in 1966 and for August through October of 1985, which was a period of a wide range in streamflows. Daily discharges observed at the Trenton gaging station in the period July 1 to September 30,1966, were lower than the corresponding simulated discharges on all but 5 of 92 days. Observed discharges were 35-40 percent lower than the simulated discharges for the lowest 50 percent of streamflows in this 3-month period. Over-estimation of low flows was less severe for upstream gaging stations on the Delaware River, which suggests that many of the ungaged tributary streams in the reach downstream from the confluence of the East and West Branches of the Delaware River had disproportionately low yields during this period of extremely low flows. Additionally, diversions from the Delaware River for public supplies and diversion into the Delaware and Raritan Canal were comparatively large at that time. The simulation of low flows at Trenton during August-October 1985, which were about 50 percent greater than those of the 1966 period, yields results comparable to those of the 1979-83 calibration, as evidenced by a root mean square error of 3.4 percent and a bias of -1.2 percent. There was no diversion to the Delaware and Raritan Canal in 1985. Flow-duration curves of observed and simulated flows for August-October 1985 are shown in figure 6. This simulation confirmed the calibrated model for reaches 1-21 for the Delaware River. Verification tests were not performed on the models for streams tributary to the Delaware River.

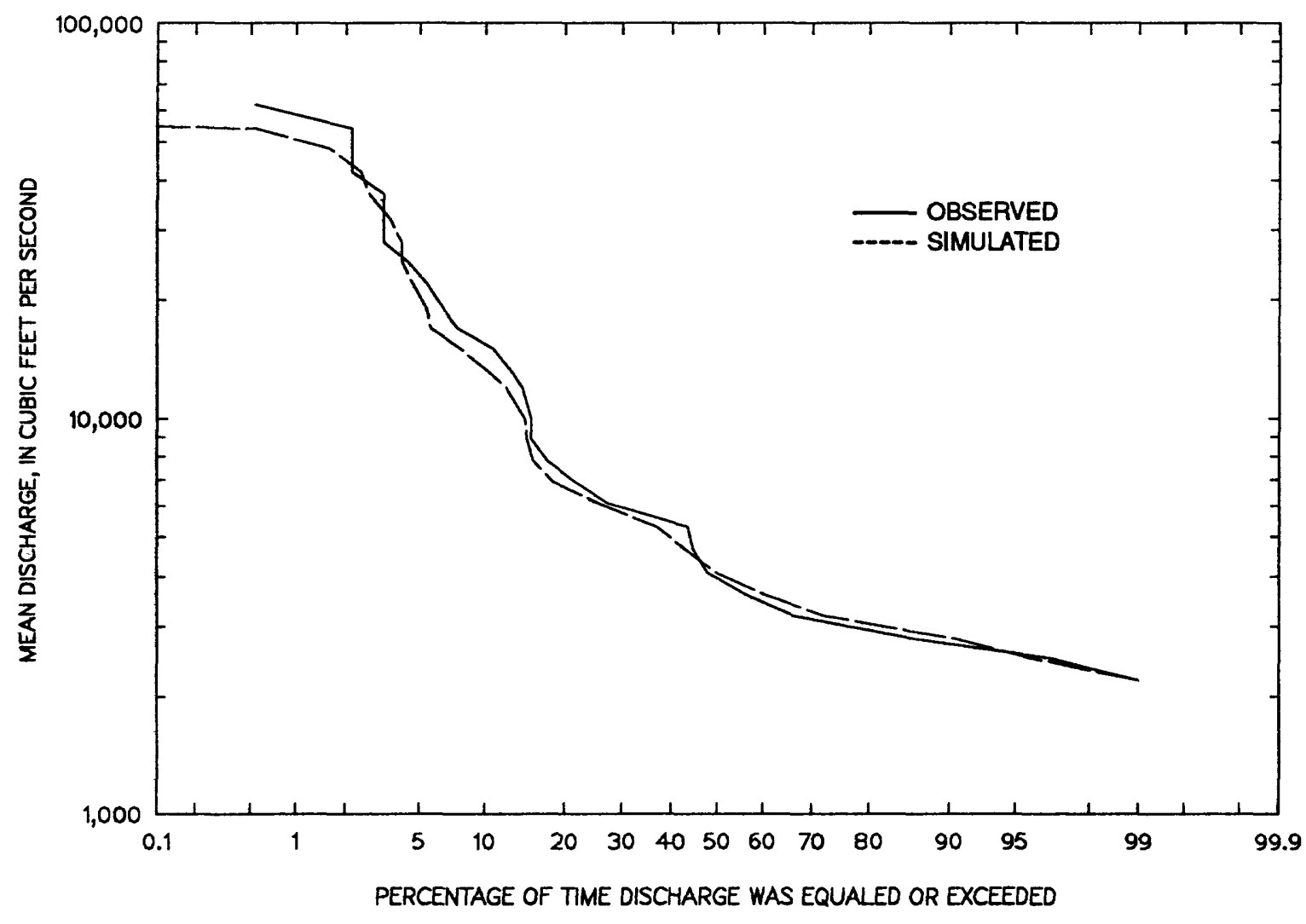

Figure 6. Cumulative-frequency distributions of observed and simulated discharge of Delaware River at Trenton, N.J., for the verification period, August-October 1985. 


\section{SUMMARY}

The Hydrologic Simulation Program - Fortran (HSPF) model that was calibrated for routing daily streamflow in the Delaware River, Lehigh River, Schuylkill River, and Brandywine Creek produced satisfactory simulations at all magnitudes of streamflow, except for approximately 2 percent of extreme highs and lows. Overall, root mean square errors for 5-year streamflow simulations for various reaches on these streams ranged between 0.4 and 9.4 percent. Considerably greater errors resulted from the calibrated models for the Lackawaxen and Neversink Rivers, which are highly regulated and for which it was necessary to estimate more than 50 percent of the inflows to the modeled reaches.

Channel-storage volume, which must be specified for selected rates of flow, is the principal variable to be determined in calibrating the RCHRES flow-routing module. Discharge-storage volume relations were developed for 31 reaches on the modeled streams. Several sets of cross-sectional data for the study reach were sufficient to begin the trial-and-error process of adjusting the discharge-volume relations of the F-tables so as to optimize the timing of the simulated hydrographs. Large adjustments in storage volumes, as well as adjustments to the slopes of some first estimates of the volume-discharge relations, were necessary to achieve timing errors of 1 day or less.

The quality of the routing calibration is commonly limited by a scarcity of suitable daily streamflow data to use in estimating ungaged inflows. These inflows were estimated by applying weighting factors, also in a trial-and-error simulation process, to selected records of gaged daily streamflows. Both the streamflow records and their weighting factors were selected to minimize simulation errors over the full range of observed flows.

Should the need arise to calibrate fully the HSPF model for rainfall-runoff or water-quality simulations in the watersheds of the modeled streams, the information presented herein will provide the components of the RCHRES modules.

\section{REFERENCES CITED}

Ayers, M. A. and Leavesley, H. G., 1988, Assessment of the potential effects of climate change on water resources of the Delaware River basin-work plan for 1988-90: U.S. Geological Survey Open-File Report 88-478, 66 p.

Ayers, M. A., Wolock, D. M., McCabe, G. J., Jr., and Hay, L. E., 1989, Hydrologic effects of climate change in the Delaware River basin: U.S. Geological Survey Yearbook-1989, p. 31-33.

Beven, K. and Kirkby, M. J., 1979, A physically based, variable contributing area model of basin hydrology: Hydrol. Sci. Bull. 24:43-69.

Hutchinson, N. E., 1975, WATSTORE users guide, volume 1: U.S. Geological Survey Open-File Report 75-246, various pagination.

Lumb, A. M., Kittle, J. L., Jr., and Flynn, K. M., 1990, Users manual for ANNIE-A computer program for interactive hydrologic analyses and data management: U.S. Geological Survey Water-Resources Investigations Report 89-4080, 236 p.

U.S. Environmental Protection Agency, 1984, Users manual for release 9.0--hydrological simulation program-FORTRAN (HSPF): EPA-600/3-84-066, Environmental Research Laboratory, Athens, Ga., $767 \mathrm{p}$.

U.S. Geological Survey, 1989, New York index to topographic and other map coverage: Reston, Va., 40 p., 1 pl.

-1990, Pennsylvania index to topographic and other map coverage: Reston, Va., 38 p., 1 pl.

Wolock, D. M., 1993, Simulating the variable-source-area concept of streamflow generation with the watershed model TOPMODEL: U.S. Geological Survey Water-Resources Investigations Report 93$4124,33 \mathrm{p}$. 